University of Nebraska - Lincoln

DigitalCommons@University of Nebraska - Lincoln

U.S. National Park Service Publications and

Papers

National Park Service

3-14-2019

Redescription of Anaschisma (Temnospondyli: Metoposauridae)

from the Late Triassic of Wyoming and the phylogeny of the

Metoposauridae

\author{
Bryan M. Gee \\ University of Toronto Mississauga, bryan.gee@mail.utoronto.ca \\ William G. Parker \\ Petrified Forest National Park \\ Adam D. Marsh \\ Petrified Forest National Park
}

Follow this and additional works at: https://digitalcommons.unl.edu/natlpark

Part of the Environmental Education Commons, Environmental Policy Commons, Environmental Studies Commons, Fire Science and Firefighting Commons, Leisure Studies Commons, Natural Resource Economics Commons, Natural Resources Management and Policy Commons, Nature and Society Relations Commons, Other Environmental Sciences Commons, Physical and Environmental Geography Commons, Public Administration Commons, and the Recreation, Parks and Tourism Administration Commons

Gee, Bryan M.; Parker, William G.; and Marsh, Adam D., "Redescription of Anaschisma (Temnospondyli: Metoposauridae) from the Late Triassic of Wyoming and the phylogeny of the Metoposauridae" (2019). U.S. National Park Service Publications and Papers. 197.

https://digitalcommons.unl.edu/natlpark/197

This Article is brought to you for free and open access by the National Park Service at DigitalCommons@University of Nebraska - Lincoln. It has been accepted for inclusion in U.S. National Park Service Publications and Papers by an authorized administrator of DigitalCommons@University of Nebraska - Lincoln. 


\title{
Redescription of Anaschisma (Temnospondyli: Metoposauridae) from the Late Triassic of Wyoming and the phylogeny of the Metoposauridae
}

\author{
Bryan M. Gee ${ }^{\mathrm{a} *}$ (D), William G. Parker ${ }^{\mathrm{b}}$ (D) and Adam D. Marsh ${ }^{\mathrm{b}}$ (D) \\ ${ }^{a}$ Department of Biology, University of Toronto Mississauga, 3359 Mississauga Road, ON L5L 1C6, Canada; ${ }^{b}$ Division of Science \\ and Resource Management, Petrified Forest National Park, 1 Park Road, PO Box 2217, AZ 86028, USA
}

(Received 12 March 2018; accepted 14 March 2019)

\begin{abstract}
Metoposaurids are non-marine temnospondyls that are among the most common constituents of Late Triassic deposits, but despite their abundance, the evolutionary relationships of the group are poorly resolved and have not been fully addressed with modern phylogenetic methods. The genus Anaschisma is one of a number of poorly resolved metoposaurid taxa and was erected to describe two species from the Popo Agie Formation (Carnian) in Wyoming: Anaschisma browni and Anaschisma brachygnatha. Since being named, the genus has been repeatedly synonymized and separated with other taxa in the context of broader revisions of the Metoposauridae. At present, Anaschisma is considered to be an indeterminate metoposaurid. Extensive descriptive work of metoposaurids since the erection of Anaschisma in 1905 and the last taxonomic review of the clade in 1993, including the naming of several new taxa and the reappraisal of several others, has generated a sufficiently detailed database through which to re-evaluate the taxonomy of the Metoposauridae as part of the analysis of phylogenetic relationships of Anaschisma. Here we reappraise and redescribe the holotypes of $A$. browni and A. brachygnatha to determine their taxonomic status and relationships in the context of an updated and revised metoposaurid phylogenetic framework. Anaschisma browni and Anaschisma brachygnatha are synonymized under the former species, as all previously listed diagnostic differences are compatible with intraspecific variation. Additionally, the well-known Koskinonodon perfectus is found to be a junior synonym of Anaschisma browni, which takes taxonomic precedence given its earlier description. Poor phylogenetic resolution of the Metoposauridae is likely the product of marked morphological conservatism within the clade and limited character sampling, although some patterns of regional clustering are apparent from the analysis.
\end{abstract}

Keywords: Anaschisma; Koskinonodon; Metoposauridae; Triassic; Popo Agie Formation

\section{Introduction}

\section{History of Anaschisma}

Metoposaurids are typically large-bodied aquatic temnospondyls that are commonly recovered from Laurasian non-marine environments of the Late Triassic. The genus Anaschisma was erected by Branson (1905) to describe two new metoposaurid taxa, Anaschisma browni and Anaschisma brachygnatha, from the Popo Agie Formation (Carnian) in Wyoming on the basis of cranial material. Since its inception, Anaschisma has been the subject of extensive revision, often as part of a broader study of the Metoposauridae. In a study of the lateral line system in extinct amphibians, Moodie (1908) suggested that $A$. brachygnatha, the smaller of the two, was a juvenile of $A$. browni and that many of the diagnostic features were either the product of ontogeny (e.g. width of skull) or intraspecific variation (e.g. orbit position). A study of the holotype specimens by Branson \& Mehl (1929) made several revisions to the original interpretation of both taxa. Most significant of these was clarification that the otic notch region had been significantly damaged, with subsequent reconstructions giving the false appearance of a shallow otic notch (Branson \& Mehl 1929). These authors maintained the taxonomic distinction between A. browni and A. brachygnatha.

Romer (1947) suggested that it was highly likely that all of the forms described from the Popo Agie by Branson \& Mehl (1929) - Anaschisma browni, Anaschisma brachygnatha, Koskinonodon princeps and Borborophagus wyomingensis (the latter two now synonymized under Koskinonodon perfectus) - were at least congeneric, and added that Buettneria (also a junior synonym of Koskinonodon (e.g. Mueller 2007)) might be as well. Colbert \& Imbrie (1956) reaffirmed the validity and diagnosis of Anaschisma in their review of the Metoposauridae, but they agreed with Moodie (1908) in considering $A$. brachygnatha to be a juvenile form of $A$. browni. Furthermore, based on morphometric analyses, they synonymized all four of the taxa from the Popo

\footnotetext{
*Corresponding author. Email: bryan.gee@mail.utoronto.ca

(C) The Trustees of the Natural History Museum, London 2019. All rights reserved. 
Agie Formation (A. browni, A. brachygnatha, $K$. princeps and $B$. wyomingensis) under one species, Eupelor browni, which was considered distinct from Eupelor durus of the Newark Supergroup and two subspecies of Eupelor fraasi from the Chinle Formation and Dockum Group. Chowdhury (1965) further reduced the family in arguing that there were no morphological differences that distinguished the European Metoposaurus from the North American Eupelor and united all metoposaurids under the former genus, leading material formerly ascribed to Anaschisma to be lumped under Metoposaurus browni with a number of other taxa.

Gregory (1980) agreed with Branson's original interpretation of shallow otic notches in material of Anaschisma as being valid, non-taphonomic features and revived the possibility of shallow otic notches as a taxonomically informative feature, leading to the restoration of Anaschisma and the assignment of a third species with a shallow otic notch from New Mexico to the genus, which he did not name. Several workers continued the trend of assigning specimens from New Mexico with shallow otic notches to Anaschisma sp. without formalizing a new species (e.g. Lucas et al. 1985; Milner 1989; Murry 1989). Hunt (1989) finally distinguished the Popo Agie Formation metoposaurids from the New Mexico taxon on the basis of elongate intercentra and a lacrimal that does not contact the orbital margin in the latter, which was formalized as Apachesaurus gregorii by Hunt (1993). The brief generic association with Apachesaurus also led Anaschisma to be briefly suggested to be a junior synonym of Dictyocephalus elegans (Davidow-Henry 1987). That taxon is represented by a single fragmentary specimen from North Carolina that was commonly identified as a juvenile metoposaurid (e.g. Colbert \& Imbrie 1956; Davidow-Henry 1987), but that is now accepted to be unresolvable below Temnospondyli indet. following Hunt (1993). The last review of the Metoposauridae (Hunt 1993) resulted in both Anaschisma browni and Anaschisma brachygnatha being designated as Metoposauridae indet. A brief overview of the Metoposauridae by Milner (1994) maintained an Anaschisma clade that included An. browni, Koskinonodon princeps (accepted by recent workers to be $K$. perfectus) and Koskinonodon maleriensis (synonymized with $K$. perfectus by Hunt [1993]). Milner (1994) recognized that the shallow otic notch in Anaschisma was the result of plaster reconstruction (or lack thereof) and instead united the taxa in this proposed clade using two synapomorphies regarding the spacing of the nares and the development of the lateral line system. In summary, misconceptions about the preservation of the
Anaschisma specimens and errors regarding the interpretation of otic notch development have resulted in Anaschisma either being designated as synonymous with Ap. gregorii (e.g. Gregory 1980) or as a nomen dubium (Hunt 1993). Hunt's taxonomic designation for material of Anaschima has otherwise been maintained.

\section{History of metoposaurid phylogenetics}

Metoposaurids have a long research history, dating back to the description of Metopias diagnosticus by Meyer (1842). Since then, at least 13 genera and 26 species have been erected, many of which have since been synonymized with other taxa or designated as nomina dubia owing to the holotype material being too fragmentary to be diagnostic; the general history of Metoposauridae is well summarized by Colbert \& Imbrie (1956) and Hunt (1993). At present, only six genera and nine species are unequivocally accepted. Three of these occur in Europe, Metoposaurus diagnosticus (Meyer 1842), Metoposaurus krasiejowensis (Sulej 2002, 2007) and Metoposaurus algarvensis (Brusatte et al. 2015), and two are known from Morocco, Dutuitosaurus ouazzoui and Arganasaurus lyazidi (Dutuit 1976). The Indian metoposaurid described as Metoposaurus maleriensis by Chowdhury (1965) is sometimes synonymized with Koskinonodon perfectus (e.g. Hunt 1993) or maintained as a separate species within Koskinonodon (e.g. Sengupta 2002), but has most recently been assigned to a new genus, Panthasaurus (Chakravorti \& Sengupta 2018). Lastly, three taxa are found in North America: Koskinonodon perfectus, 'Metoposaurus' bakeri and Apachesaurus gregorii (Hunt 1993; Long \& Murry 1995). All of these are largely restricted to south-western North America (Arizona, New Mexico, Texas) (Long \& Murry 1995), with rare documentation of ' $M$.' bakeri on the east coast (e.g. Baird 1986; Sues \& Olsen 2015) and possibly of $K$. perfectus (Doyle \& Sues 1995). As noted above, Anaschisma was considered to be a nomen dubium by Hunt (1993) and has not been reappraised since. Indeed, Mueller (2007) did not consider it in his determination of available names for the preoccupied Buettneria perfecta Case, 1922.

Hunt's (1993) review was the first study to construct a phylogenetic character matrix to assess metoposaurid phylogeny, although the analysis was not computerassisted. Hunt's analysis utilized only 12 parsimonyinformative characters for resolving ingroup relationships, and the closest utilized outgroup to the metoposaurids was the early Permian dvinosaur Trimerorhachis, which is now hypothesized to be entirely unrelated to metoposaurids (e.g. Schoch 2013). In the analysis of Hunt (1993), Apachesaurus and Arganasaurus were recovered as the most basal taxa in 
the cladogram (Hunt 1993, fig. 18). Sulej (2007, pp. 123-128) discussed possible evolutionary scenarios of the clade based on proposed changes to major differential features (e.g. lacrimal) and reconstructed conceptual phylogenies (Sulej 2007, figs. 73, 74). Since then, metoposaurids are often included in broad temnospondyl analyses, but usually only the best-known taxa (Metoposaurus diagnosticus, Dutuitosaurus ouazzoui and Koskinonodon perfectus) are utilized (e.g. Yates \& Warren 2000; Steyer 2002; Schoch 2013). The study of Schoch (2008a) describing the Middle Triassic metoposauroid Callistomordax kugleri and discussing the origin of the Metoposauridae utilized $M$. diagnosticus as the sole representative of the clade. The dissertation of McHugh (2012) was the first computer-assisted analysis to sample a majority of metoposaurids ( $K$. perfectus, 'Metoposaurus' bakeri, Apachesaurus gregorii, Metoposaurus azerouali, D. ouazzoui and Arganasaurus lyazidi) but did not include any of the European taxa known at the time (M. diagnosticus, M. krasiejowensis). Recent work by Chakravorti \& Sengupta (2018) presents a phylogeny utilizing primarily morphometric data and more complete taxon sampling, although without $A$. lyazidi and $M$. azerouali and with the inclusion of Koskinonodon howardensis (sometimes synonymized with $K$. perfectus).
Relative to other clades of stereospondyls, the taxonomy of metoposaurids is badly in need of revision, in spite of their abundant remains throughout the Late Triassic; for example, mastodonsauroids (Schoch 2000, 2008b; Damiani 2001) and brachyopoids (Warren \& Marsicano 2000) have been the subject of wholesale review via computer-assisted phylogenetic analyses, and other groups such as the non-metoposaurid trematosauroids, the plagiosauroids and the rhytidosteids are repeatedly revised in step-wise increments with modifications of existing data matrices incorporated into the description or redescription of various taxa. Conversely, a wholesale computer-assisted phylogenetic analysis of Metoposauridae in its entirety was not performed until that of Chakravorti \& Sengupta (2018), who primarily utilized continuous data obtained through morphometric analyses that were binned into discrete character states. The principle challenge that may have inhibited phylogenetic study is the marked morphological conservatism (e.g. configuration of palatal and mandibular elements) among metoposaurids. Uncertainty regarding the intraspecific variation of many traits that have been used for phylogenetic analyses further complicates matters. Finally, previous osteological descriptions of many taxa and the tendency of previous workers to preferentially present reconstructions rather than actual specimen

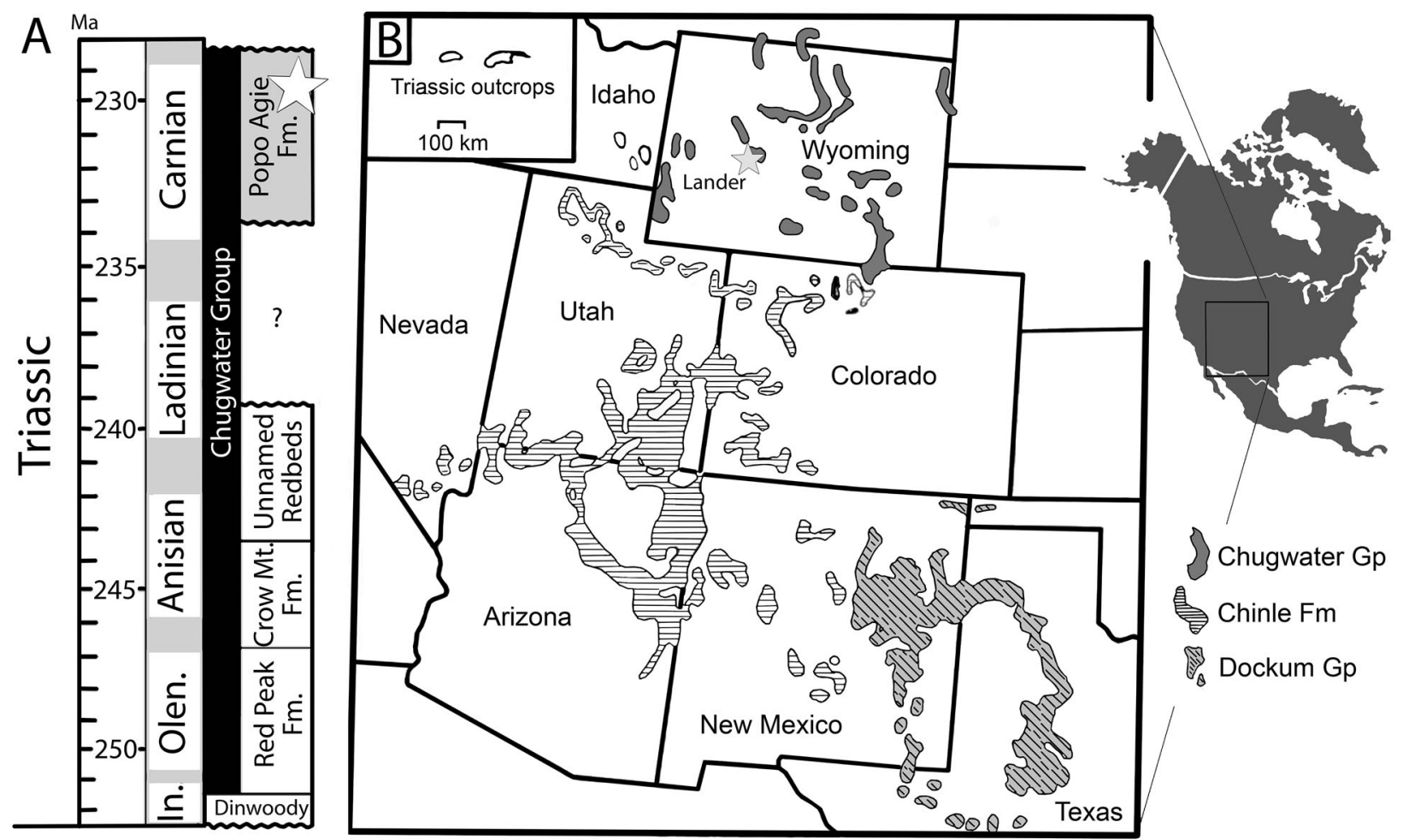

Figure 1. A, stratigraphical column indicating the approximated position of the type locality within the Popo Agie Formation. B, geographical map indicating the type locality (Lander) of Anaschisma browni and A. brachygnatha. Modified and redrawn from Lovelace \& Lovelace (2012). 
illustrations has limited the utility of the published literature. For example, the osteology of Koskinonodon perfectus, an abundant taxon throughout south-western North America, was not fully reappraised between the original and fairly brief description by Case (1922) and the description of the Rotten Hill population by Lucas et al. (2016). Other taxa remain in need of re-examination given the dated or brief nature of their descriptions (e.g. 'Metoposaurus' bakeri [Case 1932]).

In recent years, two new metoposaurid taxa (Metoposaurus krasiejowensis and Metoposaurus algarvensis) and the Middle Triassic metoposauroid Callistomordax have since been described (Sulej 2002, 2007; Schoch 2008a; Brusatte et al. 2015), the osteologies of Metoposaurus diagnosticus and Panthasaurus maleriensis have been revised (Sengupta 2002; Sulej 2002; Milner \& Schoch 2004; Chakravorti \& Sengupta 2018), and the osteologies of Apachesaurus gregorii and Koskinonodon perfectus have been expanded (Spielmann \& Lucas 2012; Lucas et al. 2016). This work has improved the characterization of interspecific variation within Metoposauridae and expanded the understanding of intraspecific and interspecific variation in a fashion that provides important insights into the original analysis of Hunt (1993). In the context of North America, much of the recent work surrounding metoposaurids has focused on Arizona, New Mexico and Texas. A need thus exists to re-evaluate material from other localities, in particular, to examine previously indeterminate material to assess whether its taxonomic position can be more tightly constrained. Here we focus on a redescription and taxonomic reappraisal of the holotype material of Anaschisma browni and Anaschisma brachygnatha from the Popo Agie Formation of Wyoming, whose taxonomy has not been fully re-evaluated since the work of Branson \& Mehl (1929).

\section{Institutional abbreviations}

$\mathbf{U C}(=$ FMNH $)$, Field Museum of Natural History, University of Chicago Collection, Chicago, IL, USA; UCMP, University of California Museum of Paleontology, Berkeley, CA, USA; WT, Panhandle Plains Museum, Canyon, TX, USA.

\section{Systematic palaeontology}

Order Temnospondyli Zittel, 1888 sensu Schoch 2013 Suborder Stereospondyli Zittel, 1888 sensu Yates \& Warren 2000

Clade Trematosauria Romer, 1947

Family Metoposauridae Watson, 1919

Genus Anaschisma Branson, 1905
1905 Anaschisma Branson: 570, figs 1-10.

1922 Buettneria Case: 13, pls 1-4, figs 1-6.

1929 Anaschisma Branson \& Mehl: 195, pls 2, 3, figs 6, 7.

1929 Borborophagus Branson \& Mehl: 217, pls 1.1, 1.2, 10-13, 15A, fig. 10.

1929 Koskinonodon Branson \& Mehl: 203, pls 4-9, figs

$8,9$.

1956 Eupelor (partim) Colbert \& Imbrie: 414, pls 25.3, 25.4, 26, 27, figs 3-7.

1965 Metoposaurus (partim) Chowdhury: 42.

1993 Metoposauridae indet. Hunt: 86.

Type species. Anaschisma browni Branson, 1905.

Revised diagnosis. Metoposaurid defined by the following differential diagnosis: differentiated from all taxa other than Metoposaurus (M. diagnosticus, M. krasiejowensis, M. algarvensis) and Panthasaurus maleriensis by the presence of a lacrimal that contacts the orbital margin; differentiated from Metoposaurus by the presence of an ornamented region of the interclavicle with a large area of reticulate pitting, a prefrontal and a lacrimal that terminate anteriorly at approximately the same level, a contact between the maxilla and the prefrontal, a jugal terminating at about the level of the anterior orbital margin, an ossified opisthotic, the absence of a deep notochordal groove on caudal intercentra, and the absence of a shallow convex kink along the anterodorsal margin of the ilium; differentiated from Panthasaurus maleriensis by frontals that taper posteriorly, a less elongate lacrimal widely separated from the naris, the absence of a sensory groove on the clavicle, larger area of reticulate ornamentation on the clavicle, the absence of a shallow convex kink along the anterodorsal margin of the ilium.

Etymology. The origin of the genus name Anaschisma is unclear, as is common for early taxonomic acts; none was ever provided by Branson (1905) or Branson \& Mehl (1929). If it can be accepted that the name has true linguistic roots (rather than from a name: e.g. Buettneria from William Buettner), then it would most likely derive from the Greek prefix 'ana-' and the Latin suffix '-schism', and the name would translate literally to 'upward division' or 'backward division', although it is unclear what morphological aspect this would refer to.

Remarks. The presence of polymorphism in the welldocumented Koskinonodon perfectus (e.g. Lucas et al. 2016) and in Metoposaurus krasiejowensis (Sulej 2007) inhibits the identification of additional differential characters at the generic level. We have identified a number of features that differentiate the most common 
morphologies of the various taxa but that are challenged by a few (or a single) specimens in which the condition differs from that considered as the generalized morphology. For example, the North American taxa (including 'Metoposaurus' bakeri) have traditionally been differentiated from the European taxa by the substantially larger region of reticulate ornamentation on the interclavicle (Colbert \& Imbrie 1956; Hunt 1993; Sulej 2002). However, Lucas et al. (2016, fig. 49C) reported one specimen (WT 3007, in part) from the Rotten Hill population with Metoposaurus-like ornamentation. Antczak \& Bodzioch (2018) also document intraspecific variability in the ornamentation of pectoral elements in $M$. krasiejowensis. Another example includes the contact between the prefrontal and the maxilla; this is prominent in $K$. perfectus and typically absent in $M$. krasiejowensis owing to an anteromedial expansion of the lacrimal, but a few specimens of the latter (Sulej 2007, figs 5, 12) feature a slight contact, and one specimen (Sulej 2007, fig. 13) features a $K$. perfectus-like contact. A third example is the relative anterior extent of the prefrontal and the lacrimal. In specimens of $K$. perfectus, the elements terminate at about the same level, in contrast to $M$. krasiejowensis in which the lacrimal typically extends farther anteriorly. However, Sulej (2007, fig. 13) noted one specimen of $M$. krasiejowensis in which the prefrontal extends past the lacrimal. Other examples include the anterior extent of the jugal relative to the orbit, the inconsistent presence of developed ornamentation on the basal plate of the parasphenoid in K. perfectus, and the contact (or separation) of the postorbital and the parietal in M. krasiejowensis. We elect to utilize features that are informative and accurately differential in the vast majority of specimens; further comments on the philosophical conundrums created by this situation and our approach are presented in the discussion section.

\section{Anaschisma browni Branson, 1905}

$$
\text { (Figs 2-6, S1, S2) }
$$

1905 Anaschisma browni Branson: 585, figs 7, 8, 10.2 . 1905 Anaschisma brachygnatha Branson: 588, figs $9,10.1$.

1922 Buettneria perfecta Case: 13, pls 1-4, figs 1-6.

1929 Anaschisma brachygnatha Branson \& Mehl: 201, fig. 7.

1929 Anaschisma browni Branson \& Mehl: 199, fig. 6. 1929 Borborophagus wyomingensis Branson \& Mehl: 217, pls 1.1, 1.2, 10-12, 15A, fig. 10 .

1929 Koskinonodon princeps Branson \& Mehl: 203, pls 4-9, figs 8, 9.
1956 Eupelor browni Colbert \& Imbrie: 422, pls 26.3, 26.4 .

1965 Metoposaurus browni Chowdhury: 42.

1993 Metoposauridae indet. Hunt: 86.

2007 Koskinonodon perfecta Mueller: 225.

2016 Koskinonodon perfectum Lucas et al.: 24, figs $27-72$.

Revised diagnosis. As for the genus.

Etymology. The species name is given for Newton $\mathrm{H}$. Brown, who discovered some of the first metoposaurid specimens from the Popo Agie Formation in 1902.

Material. UC 447, holotype skull of Anaschisma browni; UC 448, former holotype skull of Anaschisma brachygnatha.

Locality and horizon. Chugwater Group, Popo Agie Formation (late Carnian) exposures in Fremont County near Lander, WY (Fig. 1). The precise stratigraphical horizon of the material is unknown. Branson (1905) stated that S. W. Williston considered the provenance to be near the top of the Popo Agie Formation in a horizon termed the Hallopus Beds by Marsh (1891), who claimed that this horizon was the source of the enigmatic archosaur Hallopus. However, the actual geographical and stratigraphical provenance of Hallopus was unknown by Marsh, who obtained the holotype of Hallopus victor by indirect purchase from a seller in Colorado Springs, Colorado, not Wyoming. The confusing history of the 'Hallopus beds' is summarized by Ague et al. (1995), who concluded that the bed bearing the holotype of $H$. victor is from the upper Morrison Formation of Fremont County, Colorado. It may be that the shared county name resulted in Marsh's erroneous claim of provenance. The precise horizon of Anaschisma cannot even be guessed without additional diagnostic material that could roughly indicate where in the stratigraphical column it occurs. Ongoing work on a mass-death assemblage of metoposaurids (Lovelace et al. 2017; Kufner \& Lovelace 2018) may help to elucidate stratigraphical distributions of metoposaurids within the Popo Agie Formation.

\section{Description}

The following cranial description is considered representative of both specimens (UC 447, 448). Deviations are noted where appropriate, particularly with respect to areas that have been reconstructed. The skull of Anaschisma brachygnatha (UC 448) is more reconstructed than that of Anaschisma browni (UC 447). Plaster reconstruction of the former is primarily found 
A

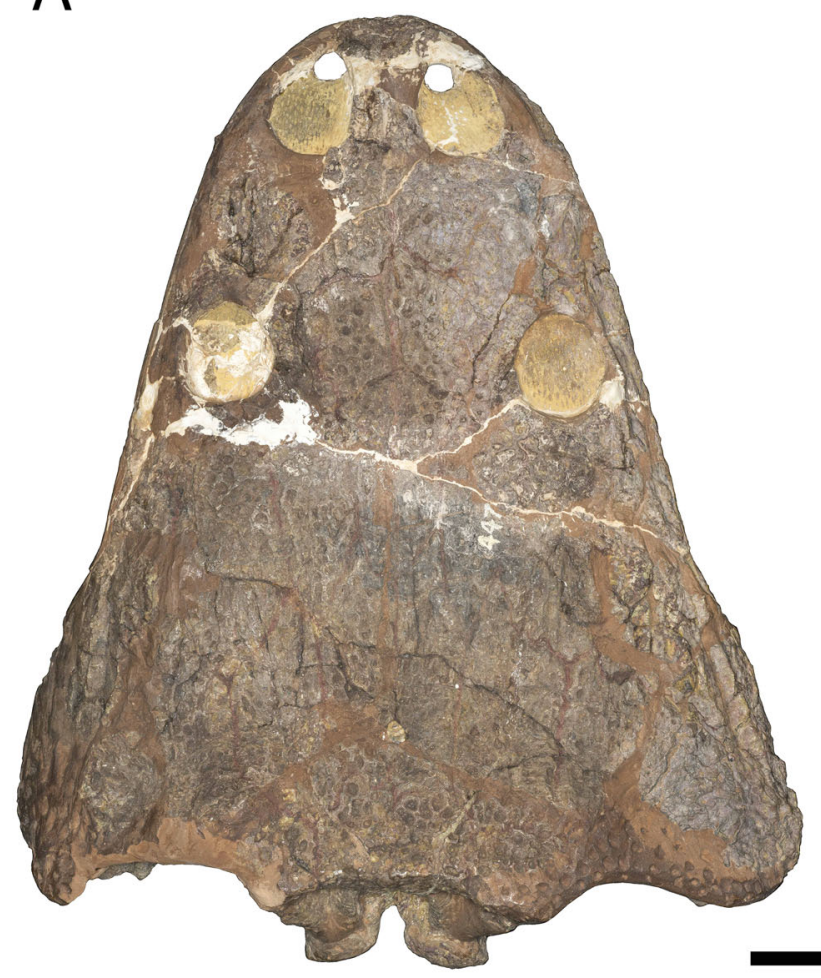

B

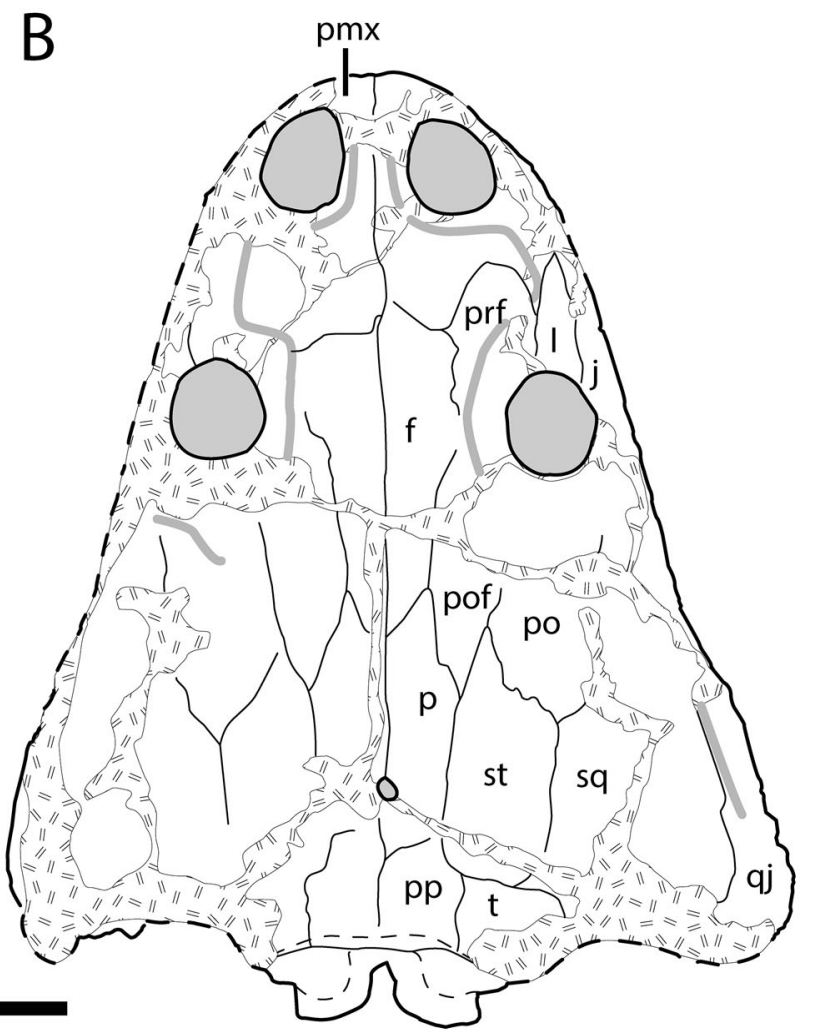

Figure 2. Anaschisma browni, skull (UC 447). A, photograph in dorsal profile and B, illustration in the same profile. Abbreviations: f, frontal; j, jugal; l, lacrimal; p, parietal; pmx, premaxilla; po, postorbital; pof, postfrontal; pp, postparietal; prf, prefrontal; qj, quadratojugal; sq, squamosal; st, supratemporal; t, tabular. Scale bar $=10 \mathrm{~cm}$.

on the lateral margins extending anteriorly from the quadratojugal, around the right naris, and around the otic notch regions, and that of the latter is primarily found on the posterior skull table and around the left naris and across large regions of the surface of the palate.

\section{Skull roof}

The premaxillae are not well preserved in either specimen, and the right counterpart is mostly reconstructed in both (Figs 2, 3). The sutural contact with the nasals (defined only in UC 448) is sufficient to identify a posteriorly projecting alary process, which extends along the medial margin of the naris to partially separate the nasal from the opening (Fig. 3). The suture between the premaxilla and the nasal is partly demarcated by the origin of the supraorbital canal, which curves posterolaterally around the naris. The nares are proportionately quite large compared to other taxa, with those of UC 447 being of subequal, if not slightly greater, size than the orbits (Fig. 2).

The maxillae are almost entirely reconstructed in UC 448 and are uninformative for comparison with other taxa (Fig. 3). They are mostly preserved in UC 447, but their sutural contacts are not as well defined (Fig. 2). All that can be confidently stated is that they are excluded from the orbital margin by the jugal and the lacrimal, in contrast to Dutuitosaurus ouazzoui (Dutuit 1976). Tooth positions are largely undefined, being demarcated only by shallow pits representing the original sockets but without clear division between sockets.

The nasals are sub-rectangular elements whose anterior suture to the premaxilla, posterior suture to the frontal, anterolateral suture to the lacrimal, and posterolateral suture to the prefrontal are fairly well defined (Figs 2,3). They are markedly asymmetrical in this specimen, with the right nasal extending farther posteriorly and the left nasal extending farther laterally; this is not uncommon among metoposaurids (see Sulej 2007 and Lucas et al. 2016, for example).

The lacrimal can only be tentatively identified in UC 448 based on its presumed position on the right side of the skull between the naris and the orbit, lateral to the nasal and anterolateral to the prefrontal, because of moderate reconstruction of the element medially; accordingly, its extent in any direction and its contribution to the orbital margin are undefined. In UC 447, the 

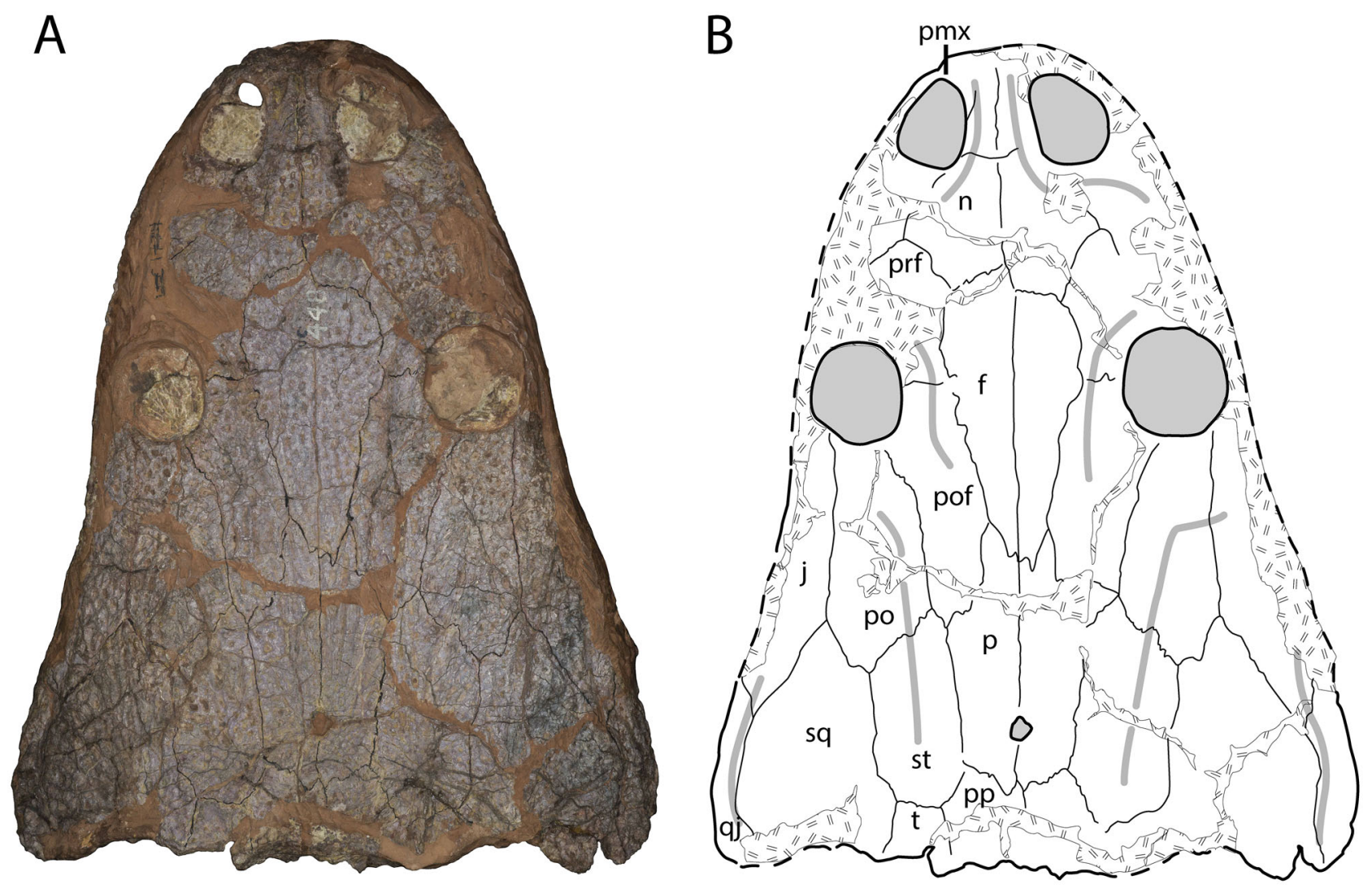

Figure 3. Anaschisma brachygnatha, skull (UC 448). A, photograph in dorsal profile and B, illustration in the same profile. Abbreviations: f, frontal; j, jugal; n, nasal; p, parietal; pmx, premaxilla; po, postorbital; pof, postfrontal; pp, postparietal; prf, prefrontal; qj, quadratojugal; sq, squamosal; st, supratemporal; t, tabular. Scale bar $=10 \mathrm{~cm}$.

lacrimal is partially defined on both sides and clearly contributes to the orbital margin (Figs 3, S1), a feature shared with the European species of Metoposaurus (but not with 'M.' bakeri) (Sulej 2002, 2007; Brusatte et al. 2015).

The prefrontals are square-shaped elements with reasonably well-defined sutures to the nasal anteromedially, to the lacrimal anterolaterally, to the frontal posteromedially, and the postfrontal posteriorly, where they contribute to the medial orbital margin. The left prefrontal of UC 448 is mostly reconstructed on its lateral and posterolateral extents (Fig. 3). The right prefrontal is mostly intact, but its lateral sutural contacts are less well defined. Those of UC 447 are not well defined but do not differ from those of UC 448 where defined (Fig. 2).

The postfrontals are elongate, sub-rectangular elements that are sutured to the prefrontal anteriorly, the frontal anteromedially, the parietal posteromedially, the supratemporal posterolaterally, and the postorbital laterally (Figs 2,3). The contact with the supratemporal is intraspecifically variable in Metoposaurus krasiejowensis (e.g. Sulej 2007, figs 5A, 9, 13), in which the contact may contribute to a quadruple junction with the postorbital and the parietal. This is seen in the right postfrontal of UC 448 in which the posterior margin is squared-off, rather than forming a tapering triangular process (Fig. 3). The contribution to the orbital margin is subequal to that of the prefrontal, in contrast to Apachesaurus gregorii (Spielmann \& Lucas 2012). The postfrontals of UC 448 are asymmetrical, which is not uncommon (see Sulej 2007 and Lucas et al. 2016, for example).

The frontals are slender, sub-triangular elements that are similar to those of other metoposaurids in tapering posteriorly along the contact with the postfrontals (Figs $2,3)$. The tapering of both specimens is most comparable to the European Metoposaurus taxa; it is more abrupt in Apachesaurus gregorii (e.g. UCMP 63845: Spielmann \& Lucas 2012) and often in 'Metoposaurus' bakeri (e.g. Case 1932, fig. 4) and Dutuitosaurus ouazzoui (e.g. Dutuit 1976, pls 6, 7). 
The parietals are slender, sub-rectangular elements that are narrowest at their anterior extent where they are sutured to the postfrontals anterolaterally and to the frontals anteriorly (Figs 2,3). The anteromedial portion forms a process that partially divides the posterior postfrontal and the posterior frontal. This is similar to most other metoposaurids except for Metoposaurus algarvensis, in which the parietals are rectangular and lack the anteromedial process (Brusatte et al. 2015). The element is longer anteroposteriorly, being similar to other metoposaurids. The parietals frame the round pineal foramen, which is situated in the posterior third of the midline suture.

The postorbitals are slender, sub-rectangular elements of a similar size to the postfrontals (Figs 2,3). They share a long medial suture to the postfrontals, a long medial suture with the jugal, a small posterolateral suture to the squamosals, and a small posteromedial suture to the supratemporals. The latter two sutures are oriented obliquely in most metoposaurids and in these specimens where the postorbitals taper to a point, although the suture to the supratemporals is sometimes more horizontal (i.e. not tapered to a strong triangular point) in Dutuitosaurus ouazzoui (Dutuit 1976, fig. 2, pl. 5) and Arganasaurus lyazidi (e.g. Dutuit 1976, pl. 49) as a result of the posterior portion being of equal width to the rest of the element.

The postparietals are square-shaped elements that form the posteromedial margin of the skull and are similar in shape and proportions across metoposaurids. In each specimen, the posterior portions are both weathered and reconstructed (Figs 2,3). The anterior sutural contact with the parietals and the anterolateral contact with the supratemporals are well preserved, but the presumed lateral contact with the tabulars is not well preserved on either side. In contrast to UC 447 (Fig. 2), the occipital condyles of UC 448 are broken off at the ends (Fig. 3), and the lack of ventral projection past the dorsal surface of the postparietals should not be interpreted as representative of the natural condition of the specimen.

The squamosal is a large, pentagonal element with well-defined sutures to the quadratojugal laterally, the jugal anteromedially, the postorbital anteriorly, the postfrontal anteromedially, the supratemporal anterolaterally, and the tabular medially (Figs 2, 3). The lateral suture is slightly convex and the lateral expansion of the element results in an anterior process that is medially offset in contrast to Apachesaurus gregorii in which the element is a symmetrical, elongate pentagon (Spielmann \& Lucas 2012). Although Arganasaurus lyazidi is sometimes illustrated as having a markedly triangular squamosal (e.g. Spielmann \& Lucas 2012, fig. 13E), this is not reflected in the specimen photos of Dutuit
(1976, pls 48-50) in which the morphology is the typical pentagon of large-bodied taxa.

The supratemporal is a slender, pentagonal element with well-defined sutures to the postfrontal anteriorly, the parietal medially, the postparietal posteromedially, the tabular posteriorly, the squamosal posterolaterally, and the postorbital anterolaterally (Figs 2, 3). Both supratemporals feature an anteriorly directed triangular process that is medially offset, as with the squamosals.

The jugals are primarily identified on the basis of their conserved position along much of the posterolateral margin of the skull roof. They suture to the quadratojugal posteriorly, the squamosal posteromedially, the postorbital medially, and at least to the maxilla anteriorly, lateral to the orbital margin (Figs 2,3). They are extensively reconstructed in UC 448 and to a lesser degree in UC 447. Whether the jugal also contacts the lacrimal, as in most metoposaurids except for Dutuitosaurus ouazzoui (Dutuit 1976), or the prefrontal, as in Apachesaurus gregorii and Arganasaurus lyazidi (Dutuit 1976; Spielmann \& Lucas 2012), is unclear, as most of the anterior portion of both jugals is reconstructed (Figs 2,3 ). The anterior extent (at the level of the anterior orbital margin or anterior to this level) is also unclear in both specimens.

The quadratojugal forms the posterolateral margin of the skull roof and is confined to a small, sub-rectangular dorsal exposure that sutures to the jugal anteriorly and to the squamosal medially (Figs 2, 3). Typically, the suture to the latter is contoured by the lateral line groove. Variation in the dorsal exposure may relate to ontogeny in which there is a general trend toward lateral expansion of the temporal region that is primarily accomplished via expansion of the quadratojugal and the squamosal.

The postparietal is a small rectangular element sutured to the parietal anteriorly, to the supratemporal anterolaterally, and to the tabular laterally (Figs 2, 3); it is conserved among metoposaurids in morphology and sutural contacts.

The tabulars are square-shaped elements smaller in size than the postparietals. They suture to the postparietal medially, to the supratemporal anteriorly and to the squamosal laterally. The left tabular is better preserved than its right counterpart in UC 448 (Fig. 3), which is mostly reconstructed, but the posterior and posterolateral margins of both tabulars are weathered, and the absence of tabular horns cannot be confidently interpreted to reflect the natural condition of the specimen. Those of UC 447 are reconstructed at the ventrolateral margin and were thus likely similarly weathered (Fig. 2). The absence of a developed tabular horn thus cannot be 

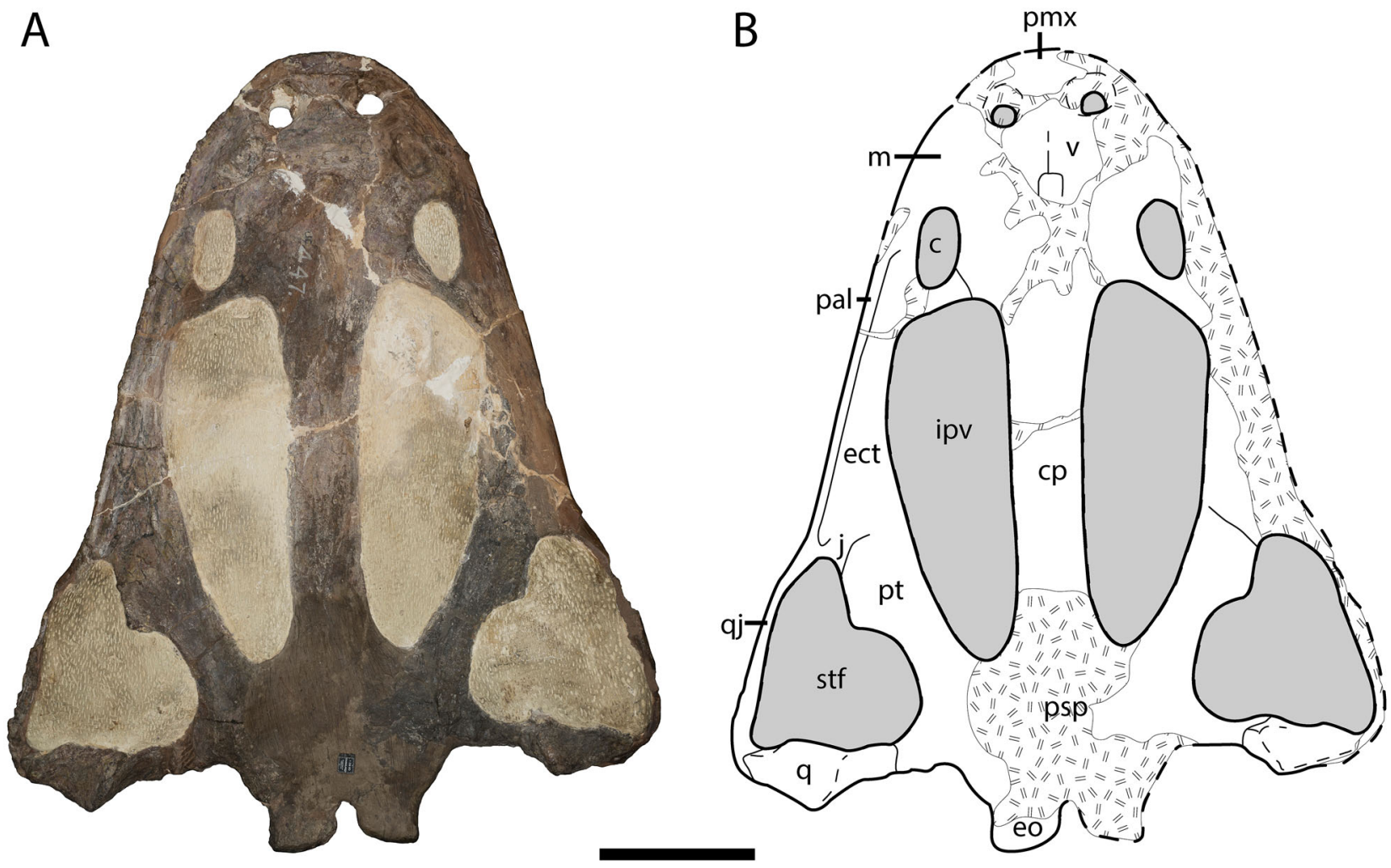

Figure 4. Anaschisma browni, skull (UC 447). A, photograph in ventral profile and B, illustration in the same profile. Abbreviations: c, choana; cp, cultriform process; ect, ectopterygoid; eo, exoccipital; ipv, interpterygoid vacuity; j, jugal; m, maxilla; pal, palatine; pmx, premaxilla; psp, parasphenoid; pt, pterygoid; q, quadrate; qj, quadratojugal; stf, subtemporal fenestra; v, vomer. Scale bar $=10 \mathrm{~cm}$.

considered taxonomically informative (contra Gregory 1980).

The ornamentation of both specimens is typical for metoposaurids, being dominated by sub-circular pitting on much of the dorsal skull roof and featuring smaller regions of elongate grooves and striations on the parietals and the quadratojugals (Figs 2,3). It is unevenly preserved and is reconstructed in many places. The lateral line grooves are not well preserved, and isolated regions are identified primarily on the basis of deep incisions in the skull roof that do not appear to be taphonomic in nature. In UC 448, only the anterior-most portion of the supraorbital canal medial to the nares and the posterior-most portion medial to the orbits is preserved (Fig. 3). The anterior extent of the temporal canal is also defined on the right side. The infraorbital canals are entirely reconstructed. The supraorbital canals are nearly complete in UC 447, featuring a prominent lateral deflection between the orbits and the nares to produce an S-shaped contour (Fig. 2). The posteromedial extent of the temporal canal is also better defined than in UC 448, and the posterior extent of the infraorbital canal is present on the right side. None of the canals differ from those identified in UC 448, and they are typical of the general pattern to which large metoposaurids conform.

\section{Palate}

The metoposaurid palate is even more highly conserved than the dorsal skull roof. Only one feature, the width of the cultriform process, has ever been maintained as a taxonomically informative feature for any appreciable timespan (e.g. Hunt 1993). Furthermore, it is only useful for differentiating large-bodied metoposaurids from Apachesaurus gregorii, in which it is markedly constricted at the mid-length (UCMP 63845: Spielmann \& Lucas 2012). Most sutures of UC 447 and UC 448 are not well or fully defined (Figs 4, 5), and the constituent elements are primarily identified by their relative position in the conservative morphological framework of metoposaurids. The following description is representative of both specimens.

The basal plate of the parasphenoid is semi-elliptical in shape, with the long axis oriented in the anteroposterior direction. There is no clear evidence for ornamentation that is well developed in some metoposaurids (e.g. Koskinonodon perfectus - Lucas et al. [2016, fig. 29B]; 

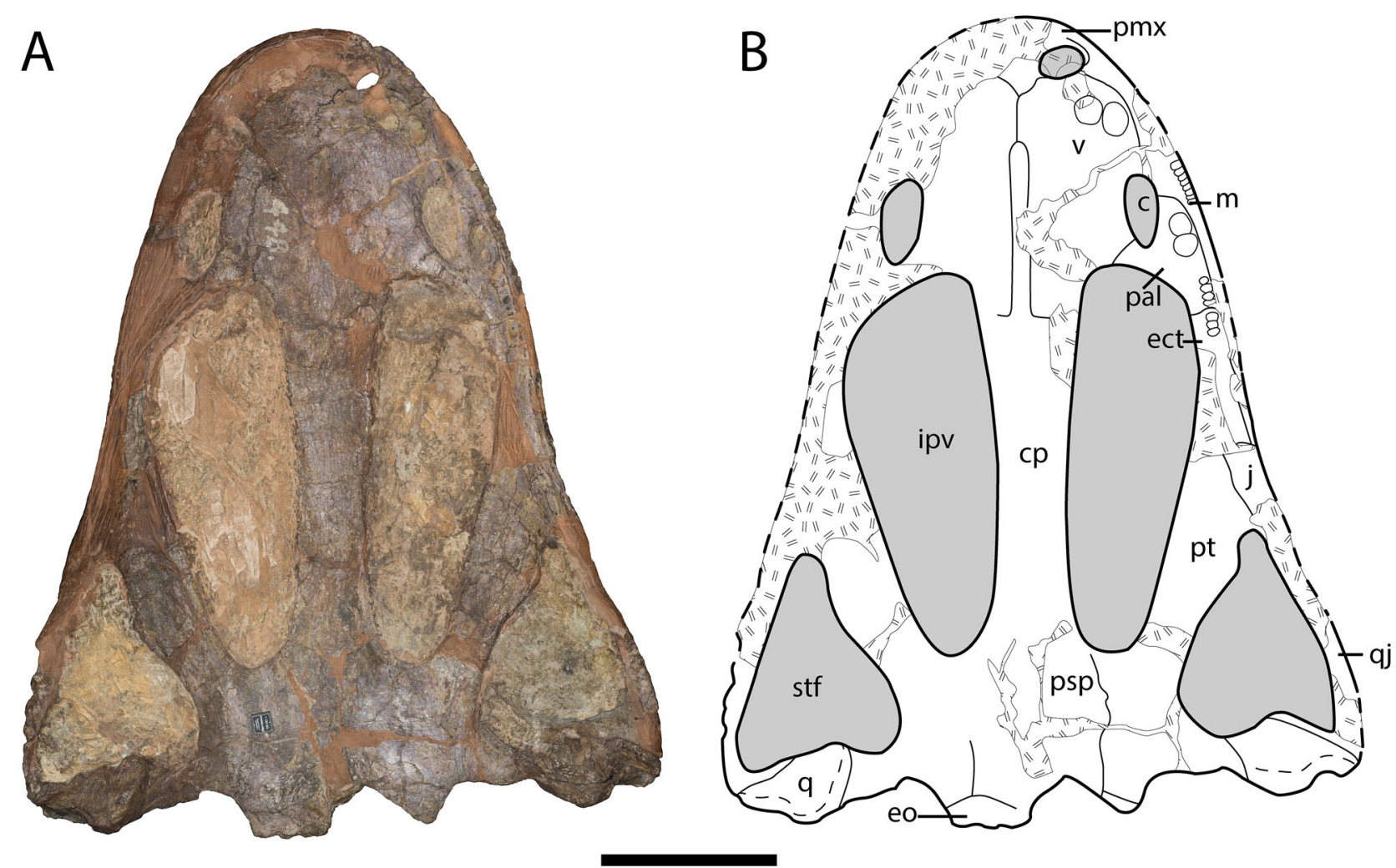

Figure 5. Anaschisma brachygnatha, skull (UC 448). A, photograph in ventral profile and B, illustration in the same profile. Abbreviations: c, choana; cp, cultriform process; ect, ectopterygoid; eo, exoccipital; ipv, interpterygoid vacuity; j, jugal; m, maxilla; pal, palatine; pmx, premaxilla; psp, parasphenoid; pt, pterygoid; q, quadrate; qj, quadratojugal; stf, subtemporal fenestra; v, vomer. Scale bar $=10 \mathrm{~cm}$.

'Metoposaurus' bakeri - Case [1932]), but the weathering of the palate may have obscured it. The cultriform process projects anteriorly from the basal plate and forms most of the medial margin of the interpterygoid vacuities. As in large-bodied metoposaurids, the process is relatively uniform in width throughout its extent. It narrows only slightly at the mid-length in UC 448 and not at all in UC 447 (Figs 4, 5). Apachesaurus gregorii is differentiated from all other taxa by a markedly narrower and more constricted cultriform process (Spielmann \& Lucas 2012). It partially divides the vomers posteriorly and terminates in the fodina vomeralis (Schoch 1999), which is well defined in UC 448 (Fig. 5 ); it is vaguely defined anteriorly by the medial suture of the vomers in UC 447 (Fig. 4). The parasphenoid is sutured posteriorly to the occipital condyles and to the pterygoid laterally; the left side of the skull of UC 448 preserves heavily interdigitated sutures at both contacts (Fig. 5).

The pterygoid is a triradiate element with three processes: a transverse (anterolateral) process directed toward the palatine, a posterolateral process directed toward the quadrate and a posteromedial process directed toward the occipital condyles in palatal profile
(Figs 4, 5). It contributes significantly to the posterior and lateral margins of the interpterygoid vacuities. A laterally directed lobe also extends into the subtemporal fenestra in the anterior portion toward the jugal; this feature is found in all metoposaurids with the possible exception of Arganasaurus lyazidi (Dutuit 1976, pl. 49). In Metoposaurus algarvensis, the flange is described as being absent, but a reconstruction of the holotype (Brusatte et al. 2015, fig. 2) shows a prominent flange on the right process that is not seen on the incomplete left process. This asymmetry can also be seen in some specimens of Dutuitosaurus ouazzoui (Dutuit 1976, pl. 45). In the latter, it cannot be determined from the figures of Dutuit (1976) if the skull has been reconstructed. The right pterygoid of UC 448 is partially reconstructed (Fig. 5). The posteromedial process is the smallest of the three and extends only a short distance along the contact with the parasphenoid to meet the occipital condyles. The suture with the condyle is only present on the right side of the skull. Both specimens are too weathered to confidently discern whether ornamentation was present on the palatine ramus (seen in 'Koskinonodon howardensis' (e.g. Sawin 1945)). 
The ectopterygoid is a rectangular element sutured to the palatine anteriorly, to the maxilla laterally, the jugal posterolaterally and the pterygoid posteromedially; only one is fully preserved in each specimen (Figs 4,5 ). It frames part of the lateral margin of the interpterygoid vacuities. It features the posterior end of the medial tooth row and is highly conserved among metoposaurids. Contrary to Branson \& Mehl (1929, p. 49, fig. 6), the ectopterygoid is not unusually reduced in Anaschisma browni, nor is it excluded from the interpterygoid vacuity, an error that was duplicated in the reconstruction of Anaschisma brachygnatha. The element labelled as the ectopterygoid is actually the ventral expression of the jugal, as was suggested by Romer (1947, p. 249). The suture between the palatine and the true ectopterygoid was originally unidentified, but it can be discerned upon closer examination.

The jugal has a small ventral exposure at the posterior termination of the paired tooth rows that sutures to the pterygoid medially and to the ectopterygoid anteriorly; as with the latter, the exposure is only preserved on one side in each specimen (Figs 4, 5). This exposure is consistent among metoposaurids; although it is not labelled as being present in illustrations of the holotype of Apachesaurus gregorii (Spielmann \& Lucas 2012, fig. 10B), there is no description that suggests a different arrangement of the palate.

The palatine is a sub-triangular element that expands transversely around the anterior margin of the interpterygoid vacuity posterior to the choana; it is preserved only on one side of each specimen (Figs 4, 5). It contains the anterior termination of the medial tooth row, which is truncated by the palatine 'fang' sockets. The posterior end of the choanal tooth row, which typically extends anteriorly along the medial margin of the choana, is not clearly defined in either specimen as a result of weathering; a few small pits likely represent this row. As with the ectopterygoid, the misidentification of the ventral expression of the jugal resulted in a mischaracterization of the element, which in this case, was regarded as being unusually long and with a process partially separating the 'ectopterygoid' and the pterygoid.

The vomer is a rectangular element that forms much of the anteromedial palate (Figs 4, 5). The vomers are primarily identified by their conserved position among metoposaurids; sutures with the palatine posterolaterally, the maxilla laterally, the premaxilla anteriorly and the cultriform process medially are not uniformly defined in either specimen. The continuation of the choanal tooth row is not well defined, but the transvomerine row, which spans the distance between the vomerine 'fang' specimens, is represented by a few poorly preserved sockets in UC 447 (Fig. 4). As with the palatine, only one pair of 'fang' sockets is present in each specimen.

The palatal exposure of the premaxilla is almost entirely reconstructed in UC 448 and is mostly identifiable by its position in UC 447 (Figs 4, 5). It appears that the latter may have fractured along the entirety of the posterior margin, as reconstruction material follows the predicted contour and is symmetrical in the skull. The fodina subrostralis media (Shishkin 1967) and some tooth sockets are discernible anteromedially. The palatal exposure of the maxilla extends for most of the lateral skull margin and contains the lateral tooth row. It features the typical medial deflection to contact the choana.

The robust, blocky quadrates are preserved in both specimens (Figs 4, 5). They are longest and deepest medially and taper laterally. Little more can be stated about them, as they are conserved in size, proportion, morphology and position throughout metoposaurids and in these specimens.

\section{Occiput}

The occiput of Anaschisma brachygnatha was never described by Branson (1905) and subsequent workers, likely because it is relatively uninformative, as most of the elements have been damaged or entirely lost and finer aspects of the morphology that could inform the taxonomy of the taxon are weathered or obscured. The occipital condyles are broken off posteriorly and the left exoccipital has been lost, preventing a characterization of the foramen magnum or the various fenestra on the exoccipitals. The only well-preserved element is the broad oblique crest of the pterygoid, which closes the subtemporal fenestra posteriorly. This extends laterally from near the midline dorsal to the quadrate ramus of the pterygoid to meet ventral extensions of the squamosal and the quadratojugal dorsally and the quadrate ventrally, which combine to frame the large, oval paraquadrate foramina.

The occiput of Anaschisma browni is more complete and was previously described and figured by Branson (1905, fig. 3, 3a). The most noteworthy feature is the contour of the foramen magnum, which is unlike that of any other metoposaurid (but probably a taphonomic artefact) and many other derived temnospondyls in lacking any apparent dorsoventral division of the opening (Fig. 6). A subdivided foramen is produced by the medial protrusion of the lamellose processes in other taxa (often erroneously identified as the supraoccipital in older works), whereas in An. browni, it is a nearly perfect oval opening. The foramen is flat ventrally and with slightly convex lateral margins that terminate in a smooth rounded dorsal margin. The only metoposaurid to confidently approach this condition is Apachesaurus, 

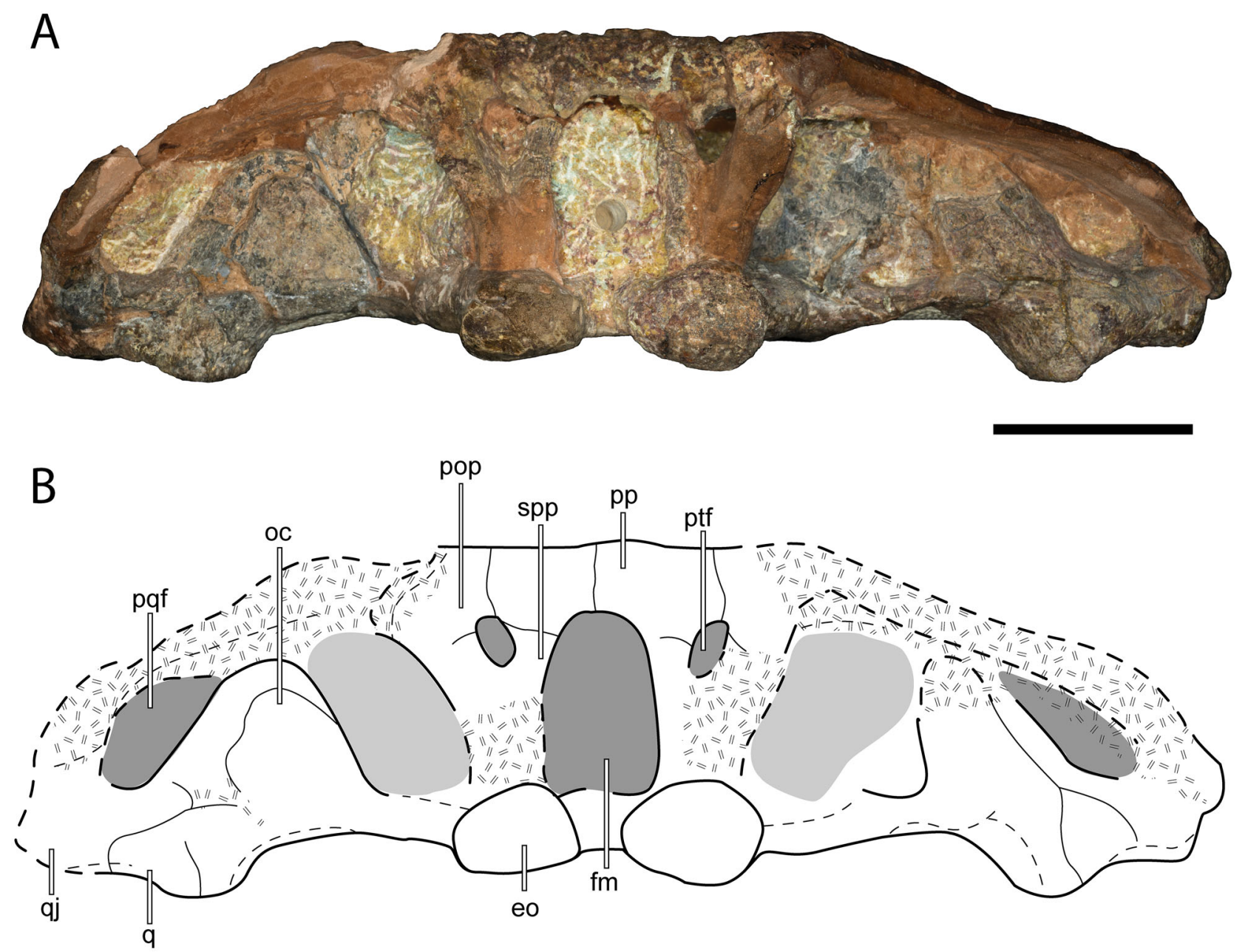

Figure 6. Anaschisma browni, skull (UC 447). A, photograph in occipital profile and B, illustration in the same profile. Abbreviations: eo, exoccipital; fm, foramen magnum; oc, oblique crest of the pterygoid; pop, parotic process; pp, postparietal; pqf, paraquadrate foramen; ptf, posttemporal foramen; q, quadrate; spp, supraoccipital process. Scale bar $=5 \mathrm{~cm}$.

but this taxon features a greater dorsal tapering, at least one markedly concave lateral margin, and a slightly concave dorsal margin (Spielmann \& Lucas 2012). There are also multiple differential features that separate An. browni from Apachesaurus gregorii, such as the extensive oblique crest, the larger and more elongate paraquadrate foramina, and aspects of the dorsal skull roof elements. The morphology of the foramen in Panthasaurus maleriensis is uncertain; one specimen figured by Chowdhury (1965, fig. 7) is more comparable to An. browni in having a nearly straight right lateral margin, which appears to be influenced by taphonomy, as the dorsal portion of the left exoccipital remains sutured to the dorsal skull roof and sharply projects medially in a typical fashion to divide the dorsal and ventral regions. However, a different specimen figured by Sengupta (2002, fig. 5B) features a short, equilateral triangular contour. This second specimen has almost certainly been affected by deformation, as the dorsal margin is significantly curved downward such that the postparietals are below the plane of the squamosals, which is atypical for metoposaurids. Figures of the holotype of $P$. maleriensis (Chakravorti \& Sengupta 2018, fig. 5) portray a poorly defined rectangular opening that is not notably subdivided. A similar artefact to that apparent in Sengupta's (2002) figure of P. maleriensis is seen in a specimen of Dutuitosaurus ouazzoui (Dutuit 1976, pl. 15C), a taxon in which the foramen magnum is typically divided (e.g. Dutuit 1976, fig. 16F). Taphonomic damage is frequently the source of variability in the foramen magnum in other taxa (e.g. Sulej 2007, fig. 16). Sulej (2007) suggested that the lamellose processes connected to the cartilaginous supraoccipital; in this regard, their absence in a large, presumably relatively mature metoposaurid is perplexing. It does not appear that the exoccipitals were entirely 
reconstructed, but given the uncertainty regarding the initial condition and preparation of the specimen (which dates to more than a century ago), the documented use of reconstructing matrix to artificially smooth surfaces in other areas of the skull (e.g. basal plate of UC 447), and the immaculate symmetry of the foramen relative to other well-preserved metoposaurid skulls, it seems most likely that the lamellose processes were broken off. The apparent absence in Ap. gregorii could be a taphonomic artefact, but it may also be ontogenetic; a partial skull (Spielmann \& Lucas 2012, fig. 16C, D) that is larger than the holotype (UCMP 63845) features a medial protrusion on the right exoccipital, and if Ap. gregorii is a juvenile metoposaurid, as we have previously suggested (e.g. Gee et al. 2017), the lack of development may reflect relative immaturity. All other aspects of the occipital morphology of UC 448 are consistent with those of UC 447.

\section{Mandible}

The left mandible of Anaschisma browni and the right mandible of Anaschisma brachygnatha were described and figured by Branson (1905). The relationship of the mandibles with the skulls during discovery and collection is not exactly clear; Branson only noted that they were collected with the skulls. As originally suggested by Branson \& Mehl (1929, pp. 190, 201), the weathering of these mandibles does not permit much characterization and no differences are apparent from that of Koskinonodon perfectus. Furthermore, the associated mandible of UC 447 could not be located during a collections visit. As such, only the more complete mandible of $A$. brachygnatha can be briefly described and figured here (Fig. S2). For the most part, reconstruction is minor and restricted to the dorsal and ventral margins, evidently for the aesthetics of smooth margins. However, the surface of the mandible is badly weathered or smoothed over with plaster such that an interpretation of the sutural patterns is not possible without heavily relying on the patterns described in other taxa.

The mandibles are long and slender, tapering slightly in height anteriorly. In typical temnospondyl fashion, the dentary is one of the largest elements, forming much of the anterolateral surface and symphysis and containing the entire tooth row. It is underlain by the lateral exposure of the angular, which expands in height posteriorly, and the surangular posteriorly. The posterior termination of the dentary is at the anterior end of a short coronoid process, which frames the adductor chamber laterally. The process is slightly damaged in both specimens. The posterior part of the mandible is formed by the retroarticular process. The lingual surface is predicted to be far more complex than figured by Branson
(1905, figs 4, 4a, 10.1), although difficulty in identifying sutures complicates a confident characterization. In Branson's reconstruction, the splenial is a large element, as anteroposteriorly long as the dentary and underlying it; it was in turn underlain by an unidentified element anteroventrally and the angular posteroventrally. Virtually the entire region figured as the splenial contains none of the actual splenial and instead, is typically formed by the precoronoid anteriorly, followed by the intercoronoid and finally by the coronoid. The unidentified element that forms the anteroventral margin of the mandible is the true splenial, which is actually separated from the angular by the postsplenial, contrary to Branson's reconstruction. Identification and contours of the prearticular and the articular are more or less in line with those of other metoposaurids. An elongate Meckelian foramen ('internal mandibular foramen' of Branson 1905) is framed by the postsplenial, the angular, and the articular; a contribution by three elements matches the reconstruction of Branson. It is reconstructed ventrally in UC 448 (Fig. S2), but the dorsal margin is complete, permitting a determination of its relative length. There is some intraspecific variation in the proportions of the foramen (e.g. Sulej 2007, fig. 20). A tooth count is unfeasible based on the weathered state of each specimen. The ornamentation of metoposaurid mandibles consistently comprises circular pitting near the ventral margin of the angular in labial profile that radiates outward into elongate grooves, but only very faint traces of this can be seen.

Brusatte et al. (2015) suggested a few characteristics of the mandible that might differentiate a subset of metoposaurid taxa. Metoposaurus algarvensis was differentiated from Metoposaurus krasiejowensis on the basis of: (1) reduced tapering in height anteriorly; (2) concave ventral margin; (3) greater maximum height of labial parapet relative to lingual parapet, but with lower termination of the former; and (4) presence of two accessory foramina on the intercoronoid dorsal to the anterior Meckelian window (Brusatte et al. 2015). They also differentiated $M$. algarvensis from Koskinonodon perfectus and Apachesaurus gregorii by the tapering in height in the latter two and the presence of a concave ventral margin, but the second character was supposedly found in M. algarvensis and was used to differentiate it from M. krasiejowensis (see the diagnosis and comments, above, versus comments in Brusatte et al. [2015, p. 9]). It should be noted that an ontogenetic influence cannot be excluded, and that more work may be necessary to quantify the variation in anterior mandible height to determine its taxonomic significance, as it appears to change throughout ontogeny in M. krasiejowensis (Sulej 2007, fig. 20). Generally, the mandibles of the two 
species of Anaschisma do not appear to taper significantly anteriorly to an even lower degree than in $M$. algarvensis, but the symphysial region is not complete in either specimen.

\section{Postcrania}

According to Branson (1905), a large number of fragmentary elements, as well as approximately 40 isolated intercentra, two nearly complete clavicles and one complete interclavicle, were recovered along with the two skulls. A 'cleithrum' was also described and photographed, but this element is in fact the broken dorsal stem of a clavicle. However, none of this material could be confidently associated with the holotype skulls, being referred only to Anaschisma sp. As a result, we do not focus on assessing this material at this time given the marked morphological similarities noted among metoposaurid postcrania. In the absence of a clear skeletal association, it should be referred to Metoposauridae indet. under an apomorphy-based identification criterion (e.g. Nesbitt \& Stocker 2008). These specimens are briefly described in the original description of Branson (1905, pp. 583-585) and in greater depth in the redescription of Branson \& Mehl (1929, pp. 197-199, pls 2, 3). The intercentra indicate only that they do not belong to Dutuitosaurus ouazzoui or to Apachesaurus gregorii in which they are proportionately more elongate. The notochordal canal on the caudal intercentrum is also shallow (Branson 1905, fig. 5.7), contrary to the latter and to Metoposaurus krasiejowensis. Although the size of the reticulated region on the interclavicle has often been cited as a differential feature between European and North American taxa, Koskinonodon perfectus is known to display the full range (e.g. Lucas et al. 2016). No sensory groove on the clavicles is apparent in the isolated specimens referred to Anaschisma sp. (Branson \& Mehl 1929).

\section{Discussion}

\section{Taxonomy of Anaschisma}

Anaschisma brachygnatha was differentiated from Anaschisma browni on the basis of several additional features: (1) proportionately narrower skull; (2) more posteriorly placed orbits; (3) more laterally placed nares; (4) finer pitting of the dermal ornamentation with broader, rounder ridges between pits; (5) posterior lateral line canals originating on the postorbitals instead of on the postfrontals; (6) narrower infratemporal foramina; and (7) internal nares positioned farther from the palatine foramina. The following section discusses the validity of each character.
The disparity in skull width is not substantial and can be attributed to ontogeny, as the posterolateral region of the skull roof may expand laterally throughout ontogeny. Small metoposaurid specimens (DavidowHenry 1987, 1989; Spielmann \& Lucas 2012; Gee \& Parker 2017, 2018) typically feature little to no lateral expansion of the temporal lobe, such that the lateral margins are straight when viewed in dorsal profile. In some large metoposaurid specimens, this lobe is expanded through the quadratojugal and the squamosal such that the lateral margins become concave posteriorly (e.g. Dutuit 1976, pl. 4; Sulej 2007, figs 4, 5; Lucas et al. 2016, figs 27G, 29E). Such variation may also naturally occur to some degree independent of ontogeny; this may, for example, be true for Panthasaurus maleriensis (e.g. Sengupta 2002, fig. 1). Brusatte et al. (2015) also discussed this difference as a means of differentiating Metoposaurus krasiejowensis and Metoposaurus algarvensis. We agree with Colbert \& Imbrie (1956, p. 423) that the alleged differences in places of the orbits and nares (features 1,2,7) are not sufficiently distinct, nor can they be excluded as ontogenetically influenced in a confident manner that would support taxonomic separation. Intraspecific variation in these features (either biological or taphonomic), especially the shape and relative size of the nares, is well documented in the mass death assemblages of $M$. krasiejowensis (Sulej 2007) and Koskinonodon perfectus (Lucas et al. 2016). The development of the ornamentation is difficult to evaluate because both specimens have been extensively weathered and subsequently reconstructed. The ornamentation is not evenly preserved throughout either skull and, as was suggested by Colbert \& Imbrie (1956), slight variation in the ornamentation is more likely to result from ontogeny than from speciation based on the similarity in ornamentation within Metoposauridae. The original basis for the lateral line character (Branson 1905, p. 586) is unclear because photographs (Branson 1905, fig. 9) and reconstructions of both specimens (Branson \& Mehl 1929, figs 6, 7) indicate that they are the same between the two purported species of Anaschisma. The grooves are also typical of the general contour seen in other metoposaurids, originating on the supratemporal, curving across the posterior portion of the postorbital and onto the jugal and then posteriorly toward the quadratojugal. The lack of substantial differences is reaffirmed in our reappraisal of the specimens. The lateral line is sufficiently preserved in Anaschisma browni to conclude that it did not contact the postfrontal. The infratemporal foramina, more commonly referred to as subtemporal fenestrae (e.g. Brusatte et al. 2015) or subtemporal windows (e.g. Sulej 2007; Spielmann \& Lucas 2012) by recent 
workers, do not differ appreciably. Both are roughly heart-shaped and of similar sizes and proportions. If anything, the transverse flange of the pterygoid may feature a slightly more developed lateral protrusion toward the ectopterygoid in UC 448, but this difference is also not appreciable or taxonomically informative. Slight intraspecific variation in the opening is typical of metoposaurids (e.g. Lucas et al. 2016, fig. 30). This is likely ontogenetically linked with the lateral expansion of the temporal region and could fall within the range of natural variation independent of ontogeny.

In sum, there is no reason to accept the taxonomic differentiation of Anaschisma brachygnatha and Anaschisma browni. Evidence in further support of their synonymy is found in their physical relationship; the two skulls were collected with one overlying the other, clearly from the same stratigraphic horizon. Where metoposaurids are known, no more than a single largebodied taxon is known to exist in a given region at a given time, which likely reflects the inability of multiple highly conserved taxa to coexist. Anaschisma browni would take precedence, as it is the first taxon to be described by Branson (1905). Furthermore, we propose the synonymy of the newly resurrected $A$. browni with the better known (because of the referral of material of Buettneria perfecta by Mueller [2007]) Koskinonodon perfectus. Firstly, we were unable to identify any distinguishing features between either specimen of $A$. browni and the plethora of specimens referred to $K$. perfectus in qualitative observations of material of both taxa. This includes comparisons made using both the properly referred material of $A$. browni (the skulls and mandibles) and informally referable material collected from the same horizon (the postcrania). Previous authors have suggested the synonymy of all of the Popo Agie metoposaurids (e.g. Romer 1947; Colbert \& Imbrie 1956; Chowdhury 1965). Furthermore, the other taxa from the Popo Agie that were described by Branson \& Mehl (1929), Koskinonodon princeps and Borborophagus wyomingensis, are accepted by other workers to be synonymous with $K$. perfectus (e.g. Hunt 1993; Mueller 2007). Finally, Romer (1947) suggested that all of the Popo Agie Formation taxa were synonymous with Buettneria (syn. Koskinonodon). The taxa do not differ in phylogenetic coding beyond the proportion of characters that can be coded for (see more details below). This conclusion can thus be considered as validation of a fairly widespread consensus among more recent workers that these taxa are synonymous. Because Anaschisma was described first (Branson 1905), it takes taxonomic precedence, with Koskinonodon reduced to a junior synonym of the former and $K$. perfectus reduced to a synonym of $A$. browni.

\section{Phylogenetic analysis}

We performed a phylogenetic analysis to hypothesize the evolutionary relationships of Anaschisma browni and to more broadly assess the interrelationships of the Metoposauridae. We utilized the character-taxon temnospondyl matrix of Schoch (2013) as an initial framework from which parsimony-informative characters were drawn. The position of Metoposauridae within Stereospondyli is well supported in recent analyses (e.g. Schoch 2013; Pardo et al. 2017) and is not reassessed here (see Schoch [2008a] for a historical summary of the phylogenetic placement of Metoposauridae). Nonmetoposaurid taxa include Sclerocephalus haeuseri (Schoch \& Witzmann 2009), Trematolestes hagdorni (Schoch 2006) and Lyrocephaliscus euri (Säve-Söderbergh 1936). We coded each species of Metoposaurus separately (M. diagnosticus, M. krasiejowensis, M. algarvensis, 'M.' bakeri) and added the North American taxon Koskinonodon perfectus, the Moroccan taxa Dutuitosaurus ouazzoui and Arganasaurus lyazidi, and the Indian taxon Panthasaurus maleriensis. Additionally, we included two taxa of more uncertain taxonomic validity and position, Metoposaurus azerouali and Anaschisma browni. We added an additional 14 characters (some parsimonyuninformative but retained for future analyses) to further resolve the relationships within Metoposauridae, resulting in a data matrix with 112 characters and 14 taxa. Character listings and scorings are provided in the Supplemental materials (Appendix 1). Taxonomic scorings are based on the following taxa and literature: Metoposaurus krasiejowensis and Metoposaurus diagnosticus (Fraas 1889; Sulej 2002, 2007); Metoposaurus algarvensis (Brusatte et al. 2015); 'Metoposaurus' bakeri (Case 1931, 1932); Koskinonodon perfectus (Case 1922; Lucas et al. 2016); Dutuitosaurus ouazzoui, Arganasaurus lyazidi and Metoposaurus azerouali (Dutuit 1976); Panthasaurus maleriensis (Chowdhury 1965; Sengupta 2002; Chakravorti \& Sengupta 2018); Anaschisma browni (Branson 1905; Branson \& Mehl 1929; this study). We scored, but elected not to include, Apachesaurus gregorii (Hunt 1993; Spielmann \& Lucas 2012 ) in this analysis given the possibility that it represents a markedly immature individual (e.g. Gee \& Parker 2018). If true, variable ontogenetic maturity among metoposaurid taxa could exert confounding influences on the phylogeny through the presence of plesiomorphic features in early stages of ontogeny (e.g. Tykoski 2005; Wiens et al. 2005; Lamsdell \& Selden 2013; Tsai \& Fordyce 2014; Woodruff et al. 2018). Including parsimony-uninformative characters in the matrix during the analysis can inflate consistency index (CI) values (Kitching et al. 1998) so we removed all 


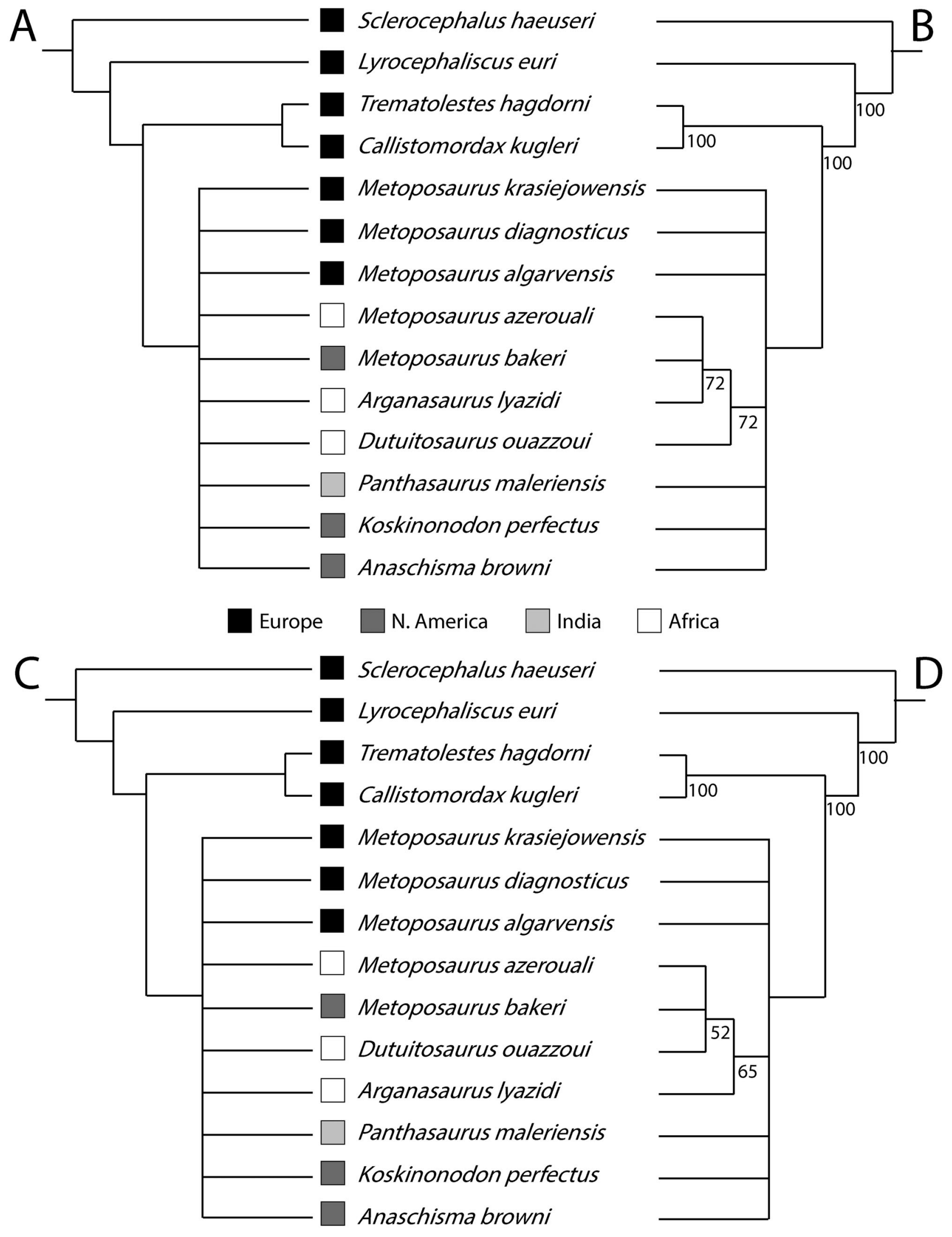


uninformative characters in the third iteration; however, we have left those characters in the matrix for future studies. With this reduced set of taxa (10), only 12 of the 112 characters are parsimony-informative for metoposaurids.

The character matrix was assembled in Mesquite (v. 3.31 for MacOS X; Maddison \& Maddison 2017) and exported as a NEXUS file. The file was analysed in PAUP* (v. 4.0b10 for 32-bit Microsoft Windows ${ }^{\mathrm{TM}}$; Swofford 2002). A heuristic search parameter was utilized with the taxa added in random order, 100 replicates per addition, holding 10 trees in memory at each step, and branch swapping with tree bisection and reconnection. The temnospondyl Sclerocephalus haeuseri Goldfuss, 1847 was utilized as the outgroup in all three iterations. Branches were set to collapse and form polytomies if the maximum branch length is zero. The trees were rooted with the outgroup. All characters were treated as unordered.

The first analysis of 14 taxa (13 ingroup) and 112 characters (44 informative) resulted in 85 most parsimonious trees (MPTs) with lengths of 132 steps; CI of 0.8333 (0.6812 excluding uninformative characters), a retention index (RI) of 0.7412 , a homoplasy index (HI) of 0.1667 (0.3188 excluding uninformative characters), and a rescaled consistency index (RC) of 0.6176 . The strict consensus of these trees (Fig. 7A) is in no way resolved due to the lack of informative characters Metoposauridae forms a single (though well-supported) polytomy. The $50 \%$ majority rule consensus tree (Fig. 7B) is slightly more resolved, producing a clade of the Moroccan taxa and 'Metoposaurus' bakeri. This clade forms a polytomy with the rest of the Metoposauridae.

A possible explanation for the total lack of resolution within Metoposauridae is the incorporation of polymorphism in this analysis. For example, all species of Metoposaurus are typically coded as having the lacrimal entering the orbit. However, in a handful of specimens of Metoposaurus krasiejowensis, the lacrimal is slightly excluded from the orbit (Sulej 2007), a feature not apparently related to taphonomy or ontogeny. In a similar vein, almost all interclavicles assigned to Koskinonodon perfectus have a large region of reticulate ornamentation, but Lucas et al. (2016) noted one inter- clavicle among the dozens collected from the Rotten Hill bonebed that has a small, Metoposaurus-like reticulate ornamented region. To test this, we removed the polymorphism coding if the described materials of a taxon were dominated by one condition (e.g. lacrimal entering the orbit in most specimens of $M$. krasiejowensis). This second iteration (14 taxa, 44 informative characters) resulted in 31 MPTs with lengths of 133 steps; CI of 0.8271 ( 0.6714 excluding uninformative characters), RI of 0.7356 , HI of 0.1729 (0.3286 excluding uninformative characters) and $\mathrm{RC}$ of 0.6084 . Both the strict consensus and the $50 \%$ majority rule consensus trees remained nearly identical in topology to the first iteration (Fig. 7C, D). The only change to topology was with respect to the clade of Moroccan metoposaurids and 'Metoposaurus' bakeri. In the first iteration, Dutuitosaurus ouazzoui was the sister taxon to a polytomy of the other three taxa (Arganasaurus lyazidi, Metoposaurus azerouali and 'M.' bakeri) (Fig. 7B); in the second iteration, A. lyazidi is now the sister taxon to a polytomy of the other three taxa (Fig. 7D). Nodal occurrence percentages for this clade are also slightly lower in the second iteration $(72 \%$ to $65 \%$ for the entire clade and $72 \%$ to $52 \%$ for the polytomy of three of the four taxa).

The third iteration of our analysis is a trimmed version of the original matrix with consensus polymorphisms removed (as with iteration 2) and with Sclerocephalus haeuseri as the outgroup and the only non-metoposauroid. Additionally, we removed taxa that are coded identically to another taxon for all characters in which both can be coded but in which one is more completely coded overall. Under this principle ('safe taxonomic reduction', sensu Wilkinson [1995]), Anaschisma browni (identical to $K$. perfectus) and Metoposaurus diagnosticus (identical to M. krasiejowensis) were removed. Additionally, we removed all parsimony-uninformative characters a priori following the taxon sub-selection, resulting in a reduced matrix with 10 taxa and accordingly only 12 parsimony-informative characters. A branch-and-bound search recovered 14 MPTs with lengths of 21 steps. The strict consensus tree remains entirely unresolved, with Metoposauridae represented by a single polytomy (Fig. 8). This is not surpris-

Figure 7. Results of the phylogenetic analysis of iterations 1 and 2 (14 taxa, 112 characters). A, strict consensus of 85 most parsimonious trees (MPTs) with lengths of 132 steps recovered in the parsimony analysis of iteration 1; Consistency Index (CI) of 0.8333 (0.6812 excluding uninformative characters), Retention Index (RI) of 0.7412 , Homoplasy Index (HI) of 0.1667 (0.3188 excluding uninformative characters), Rescaled Consistency Index (RC) of 0.6176 . B, 50\% majority rule consensus from iteration 2 . C, strict consensus of 41 MPTs with lengths of 133 steps recovered in the parsimony analysis of iteration 1 ; CI $=0.8271(0.6714$ excluding uninformative characters $), \mathrm{RI}=0.7356, \mathrm{HI}=0.1729(0.3286$ excluding uninformative characters $), \mathrm{RC}=0.6084 . \mathrm{D}, 50 \%$ majority rule consensus from iteration 2. Numbers on nodes represent the percent occurrence of that node in the most parsimonious trees. 


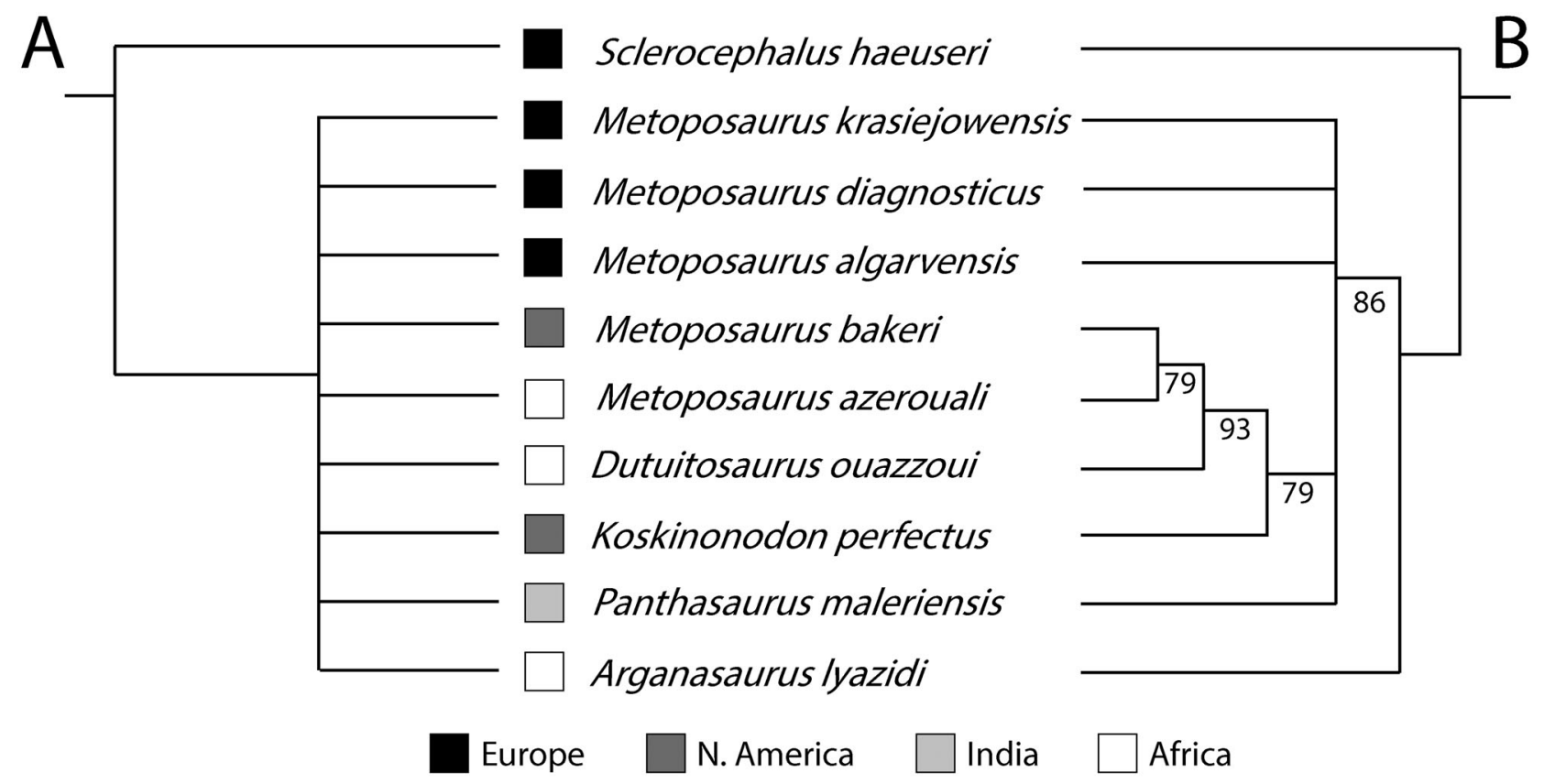

Figure 8. Results of the phylogenetic analysis of iteration 3 (10 taxa, 12 characters). A, strict consensus of 14 MPTs recovered in the branch-and-bound analysis of iteration 3. B, 50\% majority rule consensus from iteration 3 . Numbers on nodes represent the percent occurrence of that node in the most parsimonious trees.

ing given the ratio of taxa to parsimony-informative characters in this iteration. The $50 \%$ majority rule consensus tree is better resolved and differs slightly from that of the first two iterations. Arganasaurus lyazidi is the sister taxon to all other metoposaurids, and $K$. perfectus forms a clade with D. ouazzoui, Metoposaurus azerouali and 'Metoposaurus' bakeri (Fig. 8B). Because the number of taxa and parsimony-informative characters are low, a permutation tail probability (PTP) test was conducted to test whether the data contain a signal that is more significant than a random result (Faith 1991; Faith \& Crandall 1991). A value of 0.290 (nonsignificant) was recovered, further eroding support for this particular topology, as we cannot reject the null hypothesis that the resultant topology is stochastic.

Given the lack of resolution and the weak support for most recovered relationships, not much can be confidently stated about the evolutionary relationships of Metoposauridae, but a few comments are provided below. All three iterations show that the genus Metoposaurus sensu Hunt (1993) is not monophyletic, with a polytomy of the European species of Metoposaurus and the Indian Panthasaurus maleriensis forming one branch of the broader polytomy (Figs 7, 8). The non-European species of Metoposaurus ('M.' azerouali from Morocco and ' $M$.' bakeri from North America) are recovered as closely related within a polytomy or as sister taxa to each other, varying in relationship by the consensus criterion. This is an intuitive result, as the non-European species of Metoposaurus have not been revised for several decades (and nearly a century in the case of the latter), contrary to many other taxa, and are thus outdated in the current framework of metoposaurid taxonomy. Neither can be properly attributed to the genus under the diagnosis of Brusatte et al. (2015), as they lack a lacrimal entering the orbit. 'Metoposaurus' azerouali, the most poorly represented and understood of the Moroccan taxa, was classified as a nomen dubium by Hunt (1993) and has not been revised since. The original placement in Metoposaurus was made by Dutuit (1976), who also placed Dutuitosaurus ouazzoui and Arganasaurus lyazidi within the genus before they were separated by Hunt (1993).

Of these problematic taxa, 'Metoposaurus' bakeri is better represented and has been described in more detail (Case 1931, 1932) but was originally placed within Buettneria (syn. Koskinonodon) and is still in need of revision. There is a common discrepancy among workers related to how to refer to 'M.' bakeri at present, as it cannot be referred to either Metoposaurus or to Koskinonodon under the diagnoses of each given the lacrimal-orbit relationship. Some workers associate it with Metoposaurus (e.g. Sues \& Olsen 2015; this paper) following Hunt's (1993) revised designation, while others associate it with Koskinonodon or Buettneria (e.g. Sulej 2002, 2007; Brusatte et al. 2015; Lucas et al. 2016) following Case's original placement of the taxon within the now defunct Buettneria. 'Metoposaurus' 
bakeri is well described from the Dockum Group of Texas, which appears to represent a substantial geographical separation from the Argana Basin of Morocco. However, there are two lines of evidence to support a possible close relationship. The first is the temporal relationship: probably most of the metoposaurid-bearing horizons of the Argana Basin in Morocco are of late Carnian age (e.g. Khaldoune et al. 2016) and ' $M$.' bakeri is suggested to be of a similar age (e.g. Case 1931). Most other metoposaurids are probably of Norian age (or Rhaetian in the case of Apachesaurus gregorii). The second line of evidence is a nuanced geographical relationship: although ' $M$.' bakeri was first described and is best known from the Dockum Group (Case 1931), a specimen has also been collected from the Fundy Basin of Canada (e.g. Baird \& Olsen 1983; Sues \& Olsen 2015), a region that would have been adjacent to the Argana Basin. Quite possibly this region may have been an important corridor for the dispersal of metoposaurids and a close relationship between these taxa is thus neither unreasonable or unintuitive.

Based on this hypothesis, it might then be expected that Arganasaurus lyazidi, also from Morocco, would be recovered with some degree of resolution in close relationship to the above mentioned non-European taxa. Instead, it either forms a terminal branch in a metoposaurid polytomy (Fig. 7) or is recovered as the earliest diverging metoposaurid (Fig. 8). One explanation for this may be the deficiency of data for A. lyazidi, which is represented only by skulls whereas Dutuitosaurus ouazzoui and Koskinonodon perfectus are some of the best-known metoposaurids, most parts of the skeleton of 'Metoposaurus' bakeri are known from at least one specimen, and the material of 'Metoposaurus' azerouali at least includes some postcrania and mandibles. This may also explain the unresolved placement of Anaschisma browni in the first two iterations, which we have synonymized with $K$. perfectus. Although they do not form a sister relationship, A. browni and K. perfectus cannot be differentiated either in their character coding or in our qualitative observations of material of both. The recovered relationship seen in Figure 7 may thus reflect a combination of the paucity of differentiating characters in general and the lack of postcrania of $A$. browni.

Lastly, the Indian taxon Panthasaurus maleriensis (Buettneria maleriensis of Chowdhury [1965] and Sengupta [2002]) has been traditionally synonymized with Koskinonodon perfectus (e.g. Hunt 1993) but is recovered within the clade comprising the European species of Metoposaurus, corroborating the erection of a new genus by Chakravorti \& Sengupta (2018). Several features (e.g. greatly elongate lacrimal narrowly separated from the naris) differentiate $P$. maleriensis from both Anaschisma browni and from the European species of Metoposaurus (see Chakravorti \& Sengupta 2018). From a geographical standpoint, that $K$. perfectus would occur in such disparate regions as south-western North America and India and yet be absent in the adjoining regions where other metoposaurids occur, would be unexpected, so the taxonomic separation recovered here merely further substantiates Chakravorti \& Sengupta (2018). Panthasaurus maleriensis represents the most complete of the few Gondwanan occurrences of metoposaurids (the other being highly fragmentary material from Madagascar), so its relationship is less clear in the context of metoposaurid evolution and biogeography.

\section{Comparisons with previous work}

The only two phylogenetic analyses to include a majority of metoposaurid taxa are the doctoral dissertation of McHugh (2012), which broadly sampled across Temnospondyli using discrete characters, and the recent morphometric work by Chakravorti \& Sengupta (2018). Both similarly recovered a polytomy with little resolution and weak support within Metoposauridae, as in our analysis. In McHugh's (2012) analysis, the only recovered grouping was between Dutuitosaurus ouazzoui and Arganasaurus lyazidi, an intuitive relationship between Moroccan taxa. The strict consensus of Chakravorti \& Sengupta (2018) recovered Apachesaurus gregorii outside of a polytomy of all other sampled metoposaurids. We did not include Ap. gregorii because of histological data suggesting that it represents a juvenile metoposaurid (e.g. Gee et al. 2017; Gee \& Parker 2018), which would influence the phylogeny due to disparate ontogenetic maturity of the operational taxonomic units (OTUs; codings for all other metoposaurids being based on large, presumably mature specimens). The recovered earlier diverging position of Ap. gregorii despite the fact that it is probably the last and youngest metoposaurid (the type locality in the Redonda Formation is Rhaetian) provides some evidence to support this interpretation. However, without good constraints on morphological changes during metoposaurid ontogeny, marked morphological differentiation cannot automatically be ascribed to taxonomy. The histological data (Gee et al. 2017; Gee \& Parker 2018) indicating that Ap. gregorii represents a juvenile metoposaurid only further underscores this point.

\section{Considerations for metoposaurid phylogenetics}

Our results suggest that the phylogenetic relationships of metoposaurids can only be resolved through another method, such as Bayesian analyses (which allows for autapomorphies to become informative) or with more 
exhaustive sources for morphological characters such as the incorporation of morphometric data (as with Chakravorti \& Sengupta 2018). The same challenge with using discrete data motivated the morphometric approach of Chakravorti \& Sengupta (2018), but the tree remains poorly resolved and is weakly supported in their analysis. This suggests that the same intraspecific variation that we note to be problematic in our study may be applicable for continuous data as well. Variation in the proportions and relative extents of different elements is evident from large sample sizes (e.g. Sulej 2007; Lucas et al. 2016). The abundant sample size of some metoposaurids (e.g. Dutuitosaurus ouazzoui, Anaschisma browni, Metoposaurus krasiejowensis) and the paucity of others (e.g. Arganasaurus lyazidi, Panthasaurus maleriensis) would probably act as a confounding factor, as it is with the discrete characters that we utilized. Disparity in the collection and understanding of the cranial and postcranial skeleton and a lack of knowledge of metoposaurid ontogeny are additional constraints. Most of the polymorphic conditions that we identified and coded in the analysis are detected only in those taxa with a large sample size and, in almost all instances, one condition was found in a very small minority of specimens (e.g. one specimen of Anaschisma browni from the Rotten Hill population [Lucas et al. 2016] with a small area of reticulate ornamentation on the interclavicle). Even the qualitative differentiation of metoposaurids at the genus or species levels can be challenging in taxonomic diagnoses. The general lack of resolution and the deficiency of data for the two specimens of $A$. browni (no postcrania) that we re-examined here in relation to the abundant material previously referred to Koskinonodon perfectus is because they are scored identically in our matrix, supporting their proposed synonymy above.

Although the lack of resolution in our study provides few insights into the evolutionary relationships of the group from a topological perspective, it is not uninformative and arguably is not even unexpected. The results obtained here are fundamentally the result of low character sampling, but this does not necessarily reflect a paucity of work or material or a cursory approach of this study. A revised cranial osteology of four known taxa (Metoposaurus diagnosticus, Apachesaurus gregorii, Anaschisma browni, Panthasaurus maleriensis) and the osteology of two new taxa, Metoposaurus krasiejowensis and Metoposaurus algarvensis have been published in the last two decades, providing a wealth of information (Sulej 2002, 2007; Spielmann \& Lucas 2012; Brusatte et al. 2015; Lucas et al. 2016; Chakravorti \& Sengupta 2018; this study). This further emphasizes the importance of restudying historic holotypes even if those taxa are thought to be relatively incomplete or no longer taxonomically significant (Parker 2013). This recent body of work leaves the Moroccan taxa and 'Metoposaurus' bakeri as the only taxa with older (although not necessarily outdated) osteological descriptions. The body of work on metoposaurids accumulated in the last few decades should hypothetically facilitate phylogenetic differentiation of the taxa without requiring workers to personally examine the hundreds of metoposaurid specimens reposited across the world in order to produce a satisfactory level of phylogenetic resolution. Thus, the lack of resolution obtained here may reflect real aspects of metoposaurid palaeobiology, even though, strictly speaking, the results of our analyses are most directly the product of low character sampling. A similar lack of phylogenetic resolution in the analyses of McHugh (2012) and Chakravorti \& Sengupta (2018) further corroborates this.

We are not claiming that our study (or any other) is a fully comprehensive or complete metoposaurid phylogeny; we have not, for example, personally examined material outside of North America, and it is possible that such an examination could reveal additional phylogenetic characters. However, we have performed a thorough review of the literature in the hopes of elucidating more characters that might be useful for taxonomic differentiation, and the results remain quite meagre. Some of the features that we identified are autapomorphic and are thus uninformative in the context of the present parsimony-based analysis (e.g. a lacrimal that contacts the orbit in Arganasaurus lyazidi). Other characters are polymorphic in better-known taxa (e.g. size of reticulate ornamented area on the interclavicle), and the remainder are poorly known in many taxa (most non-pectoral postcranial characters). There may be additional features that are useful for identification of specimens or more qualitative differentiation of taxa but that are difficult to incorporate into a phylogenetic analysis (e.g. relative height of labial wall of the mandible; see Supplementary material for more details). The high degree of morphological similarity across all known metoposaurid taxa has long been recognized (e.g. Romer 1947; Colbert \& Imbrie 1956). Furthermore, recent work on the clade (e.g. Sulej 2007; Lucas et al. 2016) seems to actually confound attempts to discretely bin taxa because of a greater recognition of intraspecific variation in large samples (see also Antczak \& Bodzioch 2018; Teschner, Sander, \& Konietzko-Meier 2018). It is thus our interpretation that while the lack of taxonomic resolution is a direct result of low character sampling, the latter is influenced by a real biological phenomenon, namely the lack of morphological 
variation within Metoposauridae. This is not unique to metoposaurids; for example, the same issue in the postcranial skeleton of phytosaurs hinders our phylogenetic understanding of that group as well (Griffin et al. 2017).

\section{Philosophical considerations}

The particular case of metoposaurids introduces some philosophical conundrums as it relates to taxonomic classification and the diagnosis of extinct taxa in general. The convention of morphological species delimitation (i.e. de Queiroz 2007) is to compare all relevant specimens to a holotype specimen to make referral determinations; in formal practice, this manifests as a system of apomorphy-based identification (Bell et al. 2004; Nesbitt \& Stocker 2008; Lessner et al. 2018). However, this method can result in excessive taxonomic splitting at lower taxonomic levels (to say nothing of the challenges of outdated diagnoses) because it is inherently narrow in scope - a single specimen cannot capture the entire morphological range of a given taxon (particularly given the incompleteness of most fossils), and the holotype may not always be a good exemplar of the generalized morphology of that taxon. This has long been a problem with respect to metoposaurids that, split among their peak hypothesized taxonomic diversity, included more than twice as many genera and species than are presently recognized. This has often occurred by virtue of past workers ascribing very minor differences to taxonomy when they may very well represent intraspecific variation or taphonomic deformation (a 'taphotaxon' of Lucas 2001). The best example of this is Anaschisma browni, which now includes Koskinonodon (Buettneria) perfectus, Koskinonodon princeps, Buettneria howardensis, Buettneria major, Kalamoiketor pinkleyi and Boroborophagus wyomingensis (all named in the early twentieth century) among its junior synonyms (Mueller 2007; this study).

The challenges are compounded in metoposaurids because of the remarkable morphological conservatism within the clade and because of the atypically large sample size available for some taxa (Dutuitosaurus ouazzoui, Metoposaurus krasiejowensis, Anaschisma browni). The latter has provided a better picture of intraspecific variation but has also further complicated the formal diagnoses and phylogenetic coding of metoposaurids. For example, it is widely accepted that the lacrimal enters the orbit in $A$. browni and the European species of Metoposaurus. However, Sulej's (2007) work on M. krasiejowensis identified a very small minority among several dozen specimens in which the lacrimal does not enter the orbit on at least one side. Under an apomorphy-based identification, these specimens would be referred to Metoposauridae indet. because they do not align with the formalized diagnostic lacrimal-orbit relationship. However, there is no good reason to propose that these specimens represent different taxa based on this one small difference, and it is not suggested that these few specimens represent a known genus in which the lacrimal is excluded (e.g. the Moroccan taxa). In most instances, such variation is only detected in large sample sizes represented by mass death assemblages that can be reasonably inferred to represent a single population. To formally consider these as discrete taxa would be a return to the excessive taxonomic splitting of classical workers. As we noted in the remarks section, similar observations (e.g. one specimen of M. krasiejowensis with a prefrontal extending anteriorly past the lacrimal; one interclavicle of $A$. browni from Rotten Hill with a small area of reticulate pitting) presented challenges in the revised diagnosis of Anaschisma browni that we present here.

As reflected in the diagnosis, we have elected to utilize those characters that are nearly always informative for taxonomic differentiation. If we excluded all features of this kind, there would be no way to differentiate Metoposaurus and Anaschisma by their skull roofs (the most common skeletal region used in diagnoses). This is not because the taxa are identical and should be synonymized, but rather because there are a small handful of specimens of one genus that exhibit the condition of the other for a number of otherwise largely informative features (e.g. prefrontal-maxilla contact). Strictly speaking from an apomorphy-based standpoint and using the revised genus-level diagnosis of Metoposaurus by Brusatte et al. (2015), isolated skulls of Metoposaurus and Anaschisma cannot be differentiated because they share the lacrimal-orbit relationship and are otherwise only differentiated by postcrania. Excluding such features would thus make it impossible to properly refer any specimen to either genus without associated diagnostic postcrania (an extremely rare occurrence). We have also elected to score polymorphic conditions for taxa in which such features (e.g. lacrimal-orbit relationship in Metoposaurus krasiejowensis) vary. Even though one condition may be far more prevalent in a given taxon, that should not imply that one is more 'normal', and the scoring should reflect the strict observational data rather than interpretations of such variations. The taxonomic approach that we elect to follow here reflects both the pragmatic realities of taxonomic identification and what we feel is a more accurate reflection of the nuances of intraspecific (or higher taxonomic levels) variation. It may be tempting to also rely on traditional interpretations of geographical extent to identify metoposaurids (e.g. that Metoposaurus sensu Brusatte et al. 
[2015] is found only in Europe). Such notions have strongly influenced previous workers' ideas about the taxonomy of the group (e.g. Colbert \& Imbrie 1956). However, caution should be exercised in identifying specimens using this method, especially outside of bonebed assemblages, as the known geographical and stratigraphical ranges (especially those known only from bonebeds) almost certainly underestimate the true ranges due to gaps in the fossil record.

A final related consideration in this discussion is whether the metoposaurids should be distributed among so many taxa (six genera and at least nine species at present) when the level of disparity is so low compared to other temnospondyl clades. Although the excessive taxonomic splitting (10 genera and 19 species) that plagued the group over a century ago has been fairly well rectified by past workers (e.g. Colbert \& Imbrie 1956; Hunt 1993), various workers have either informally or formally proposed further synonymy. Colbert \& Imbrie (1956) proposed creating subspecies for a single North American species (resulting in three genera and five species). This was similarly followed by Sulej (2002) with respect to the European taxa, but as noted by Brusatte et al. (2015), this is a rare practice within the discipline. The most extreme approach is that of Chowdhury (1965), who used the same subspecies approach as Colbert \& Imbrie (1956) to place all metoposaurids within five species that were all grouped into a single genus, Metoposaurus. Chakravorti \& Sengupta (2018) briefly mention the possibility for some taxa to represent subspecies of other taxa (as with Sulej 2002), but the philosophical concerns associated with subspecies designations in palaeontology (e.g. Simpson 1943; Brusatte et al. 2015) typically prevent such acts. The absence of phylogenetic resolution should not be interpreted as an unequivocal line of evidence to support this idea. Too often paleontologists are concerned with how species are distributed among genera in an attempt to address macroevolutionary questions regarding taxonomy, variation, geographical ranges and taxon duration. However, these processes occur at the species level and should only be studied at that level (Hendrix et al. 2014; Parker 2018). This has certainly been a historical challenge for metoposaurids, and additional work by various independent workers is necessary to approach and to examine the taxonomy of the group through quantitative methods. Nonetheless, the possibility exists that at least some of the morphological distinctions currently ascribed to generic differentiation should be considered as within a normative range of variation within a single species. The increased documentation of polymorphism in taxa represented by large samples lends some support to this idea.

\section{Conclusions}

Despite being well represented in the fossil record, sometimes by dozens of specimens for a single taxon, the evolutionary history and relationships of metoposaurids remain remarkably poorly resolved. As discussed extensively above, the high rate of morphological conservatism in the clade, in conjunction with some degree of polymorphism in the better-known taxa, presents challenges for phylogenetic analyses using discrete and continuous data. The lack of well-constrained absolute ages for most metoposaurid-bearing horizons is a major confounding variable with respect to a better temporal and geographical understanding of metoposaurid evolution. The Moroccan metoposaurids and 'Metoposaurus' bakeri are probably closely related, a weakly supported but recovered relationship in our analysis, given that they are late Carnian taxa and occur in geographically adjacent areas. However, the direction(s) and timing of dispersal of metoposaurids, especially into Gondwana, remain unclear. The Middle Triassic (Ladinian) metoposauroid, Callistomordax, is known only from Germany (Schoch 2008a). The broad temporal gap between its occurrence and undisputed Carnian-aged metoposaurids (Dutuitosaurus ouazzoui, Anaschisma browni, 'M.' bakeri), none of which occur in Europe, complicates the matter. Based on these taxa, a few observations may be noted. Anaschisma browni and 'M.' bakeri geographically overlap only in the Dockum Group of Texas, where they do not co-occur; the former primarily occurs in the Tecovas Formation, while the latter occurs in the older Camp Springs Formation (e.g. Hunt 1993). Anaschisma browni is found further to the west in the Carnian- and Norian-aged sediments of Arizona, New Mexico and Wyoming (Branson \& Mehl 1929; Hunt 1993; Long \& Murry 1995), whereas ' $M$.' bakeri is unknown west of Texas. Furthermore, 'M.' bakeri is not found in Norianaged sediments, whereas $A$. browni reaches its peak abundance in the Norian, being among the most abundant vertebrate fossils recovered in the well-sampled deposits of early to middle Norian age. Thus, as suggested by Sulej (2007), 'M.' bakeri is most likely the oldest North American metoposaurid. Beyond this, little more can be confidently characterized in the absence of radioisotopic dates or a more refined global biostratigraphy. The Moroccan specimens are generally accepted to be of late Carnian age (e.g. Khaldoune et al. 2016), but their relative age to the North American taxa of a probable Carnian age is unknown. Previous attempts to correlate Moroccan and North American depositional basins are somewhat questionable (e.g. Kammerer et al. 2012, pp. 281-282). Additionally, the age of the European deposits is only constrained between late 
Carnian and early Norian (e.g. Brusatte et al. 2015; Szulc et al. 2015). The only relationship that can be confidently defined is that Metoposaurus diagnosticus precedes M. krasiejowensis (Sulej 2002; Milner \& Schoch 2004). The same constraint is true of the lower Maleri Formation from which Panthasaurus maleriensis is known (Novas et al. 2011; Chakravorti \& Sengupta 2018). Accordingly, it is unclear whether ' $M$.' bakeri represents a taxon similar to the hypothesized evolutionary ancestor of all metoposaurids, thereby indicating a North American origin and subsequent eastward dispersal, or if metoposaurids originated elsewhere. Given the challenges associated with resolving metoposaurid phylogenetics, absolute dates of metoposaurid-bearing horizons are essential for further characterizing the evolution of the clade. Lastly, phylogenetic approaches outside of parsimony methods that use discrete data should be explored to see whether they can produce a higher resolution among evolutionary relationships of the metoposaurids.

\section{Acknowledgements}

Thanks to Bill Simpson (Field Museum) for providing initial photographs, granting Mike Eklund access to the specimens and facilitating a collection visit by BMG. Thanks to Mike Eklund for photography of the specimens. Thanks to Tomasz Sulej and Jean-Sébastien Steyer for constructive reviews that improved this manuscript. This is Petrified Forest National Park Paleontological Contribution No. 58. The views presented herein are those of the authors and not necessarily those of the United States Government. We dedicate this paper to the memory of Bill Mueller who worked tirelessly to further our understanding of Late Triassic paleontology in the southwestern U.S.

\section{Supplemental material}

Supplemental material for this article can be accessed here: https://doi.org/10.1080/14772019.2019.1602855.

\section{ORCID}

Bryan M. Gee (D) http://orcid.org/0000-0003-4517-3290 William G. Parker (D) http://orcid.org/0000-00026005-7098

Adam D. Marsh (D) http://orcid.org/0000-00023223-8940

\section{References}

Ague, J. J., Carpenter, K. \& Ostrom, J. H. 1995. Solution to the Hallopus enigma? American Journal of Science, 295, 1-17.

Antczak, M. \& Bodzioch, A. 2018. Ornamentation of dermal bones of Metoposaurus krasiejowensis and its ecological implications. PeerJ, 6, e5267. doi:10.7717/peerj.5267.

Baird, D. 1986. Some Upper Triassic reptiles, footprints, and an amphibian from New Jersey. The Mosasaur, 3, 125-153.

Baird, D. \& Olsen, P. E. 1983. Late Triassic herpetofauna from the Wolfville Fm. of the Minas Basin (Funday Basin) Nova Scotia, Canada. Geological Society of America, Abstracts with Program, 15, 122.

Bell, C. J., Head, J. J. \& Mead, J. I. 2004. Synopsis of the herpetofauna from Procupine Cave. Pp. 117-126 in A. D. Barnosky (ed.) Biodiversity response to climate change in the Middle Pleistocene: the Porcupine Cave fauna from Colorado. University of California Press, Berkeley, CA.

Branson, E. B. 1905. Structure and relationships of American Labyrinthodontidae. The Journal of Geology, 13, 568-610.

Branson, E. B. \& Mehl, M. G. 1929. Triassic amphibians from the Rocky Mountain region. The University of Missouri Studies, 4, 154-253.

Brusatte, S. L., Butler, R. J., Mateus, O. \& Steyer, J. S. 2015. A new species of Metoposaurus from the Late Triassic of Portugal and comments on the systematics and biogeography of metoposaurid temnospondyls. Journal of Vertebrate Paleontology, 35, e912988. doi:10.1080/ 02724634.2014 .912988$.

Case, E. C. 1922. New reptiles and stegocephalians from the Upper Triassic of western Texas. Carnegie Institute of Washington, 321, 7-84.

Case, E. C. 1931. Description of a new species of Buettneria, with a discussion of the brain case. Contributions from the Museum of Paleontology, University of Michigan, 3, 187-206.

Case, E. C. 1932. A collection of stegocephalians from Scurry County, Texas. Contributions from the Museum of Paleontology, University of Michigan, 4, 1-56.

Chakravorti, S. \& Sengupta, D. P. 2018. Taxonomy, morphometry and morphospace of cranial bones of Panthasaurus gen. nov. maleriensis from the Late Triassic of India. Journal of Iberian Geology. doi:10.1007/s41513018-0083-1.

Chowdhury, T. R. 1965. A new metoposaurid amphibian from the Upper Triassic Maleri Formation of Central India. Philosophical Transactions of the Royal Society of London, Series B, 250, 1-52.

Colbert, E. \& Imbrie, J. 1956. Triassic metoposaurid amphibians. Bulletin of the American Museum of Natural History, 110, 399-452.

Damiani, R. J. 2001. A systematic revision and phylogenetic analysis of Triassic mastodonsauroids (Temnospondyli: Stereospondyli). Zoological Journal of the Linnean Society, 133, 379-482.

Davidow-Henry, B. 1987. New metoposaurs from the southwestern United States and their phylogenetic relationships. Unpublished MSc thesis. Texas Tech University, $76 \mathrm{pp}$.

Davidow-Henry, B. 1989. Small metoposaurid amphibians from the Triassic of western North America and their 
significance. Pp. 278-292 in S. G. Lucas \& A. P. Hunt (eds) Dawn of the age of dinosaurs in the American southwest. New Mexico Museum of Natural History and Science, Albuquerque.

de Queiroz, K. 2007. Species concepts and species delimitation. Systematic Biology, 56, 879-886.

Doyle, K. D. \& Sues, H.-D. 1995. Phytosaurs (Reptilia: Archosauria) from the Upper Triassic New Oxford Formation of York County, Pennsylvania. Journal of Vertebrate Paleontology, 15, 545-553.

Dutuit, J. M. 1976. Introduction à l'étude paléontologique du Trias continental marocain. Description des premiers stegocephales recueillis dans le couloir d'Argana (Atlas occidental). Memoires du Museum National d'Histoire naturelle, Paris, Series $C, \mathbf{3 6}, 1-253$.

Faith, D. P. 1991. Cladistic permutation tests for monophyly and nonmonophyly. Systematic Biology, 40, 366-375.

Faith, D. P. \& Cranston, P. S. 1991. Could a cladogram this short have arisen by chance alone? On permutation tests for cladistic structure. Cladistics, 7, 1-28.

Fraas, E. 1889. Die Labyrinthodonten der schwäbischen Trias. Palaeontographica, 36, 1-158.

Gee, B. M. \& Parker, W. G. 2017. A juvenile Koskinonodon perfectus (Temnospondyli, Metoposauridae) from the Upper Triassic of Arizona and its implications for the taxonomy of North American metoposaurids. Journal of Paleontology, 91, 1047-1059.

Gee, B. M. \& Parker, W. G. 2018. Morphological and histological description of small metoposaurids from Petrified Forest National Park, AZ, USA and the taxonomy of Apachesaurus. Historical Biology. doi: 10.1080/08912963.2018.1480616.

Gee, B. M., Parker, W. G. \& Marsh, A. D. 2017. Microanatomy and paleohistology of the intercentra of North American metoposaurids from the Upper Triassic of Petrified Forest National Park (Arizona, USA) with implications for the taxonomy and ontogeny of the group. PeerJ, 5, e3183. doi:10.7717/peerj.3183.

Goldfuss, A. 1847. Beiträge zur vorweltlichen Fauna des Steinkohlegebirges. Naturhistorischer Verein der Preussischen Rheinlande, Bonn, 27 pp.

Gregory, J. T. 1980. The otic notch of metoposaurid labyrinthodonts. Pp. 125-135 in L. L. Jacobs (ed.) Aspects of vertebrate history. Museum of Northern Arizona Press, Flagstaff.

Griffin, C. T., Stefanic, C. M., Parker, W. G. Hungerbühler, A. \& Stocker, M. R. 2017. Sacral anatomy of the phytosaur Smilosuchus adamanensis, with implications for pelvic girdle evolution among Archosauriformes. Journal of Anatomy, 231, 886-905.

Hendrix, J. R., Saupe, E. E., Myers, C. E., Hermsen, E. J. \& Allmon, W. D. 2014. The generification of the fossil record. Paleobiology, 40, 511-528.

Hunt, A .P. 1989. Comments on the taxonomy of North American metoposaurs and a preliminary phylogenetic analysis of the family Metoposauridae. Pp. 293-300 in S. G. Lucas \& A .P. Hunt (eds) Dawn of the age of dinosaurs in the American southwest. New Mexico Museum of Natural History and Science Bulletin, Albuquerque.

Hunt, A. P. 1993. Revision of the Metoposauridae (Amphibia: Temnospondyli) and description of a new genus from western North America. Museum of Northern Arizona Bulletin, 59, 67-97.
Kammerer, C. F., Nesbitt, S. J. \& Shubin, N. H. 2012. The first silesaurid dinosauriform from the Late Triassic of Morocco. Acta Palaeontologica Polonica, 57, 277-284.

Khaldoune, F., Jalil, N.-E., Germain, D. \& Steyer, J.-S. 2016. Les vertébrés du Permien et du Trias du Maroc (bassin d'Argana, Haut-Atlas occidental): une fenetre ouverte sur l'évolution autour de la grande crise finipaléozoïque. Mémoires de la Société Géologique de France, 180, 103-167.

Kitching, I. J., Forey, P. L., Humphries, C. J. \& Williams, D. M. 1998. Cladistics: the theory and practice of parsimony analysis. Oxford University Press, New York, $195 \mathrm{pp}$.

Kufner, A. M. \& Lovelace, D. M. 2018. Taphonomy of two Late Triassic stereospondyl mass death assemblages from the Popo Agie Formation (Fremont County, Wyoming). Journal of Vertebrate Paleontology, Program and Abstracts, 2018, 162.

Lamsdell, J. C. \& Selden, P. A. 2013. Babes in the wood - a unique window into sea scorpion ontogeny. $B M C$ Evolutionary Biology, 13, 98. doi:10.1186/1471-2148-1398.

Lessner, E. J., Parker, W. G., Marsh, A. D., Nesbitt, S. J., Irmis, R. B. \& Mueller, B. D. 2018. New insights into Late Triassic dinosauromorph-bearing assemblages from Texas using apomorphy-based identifications. PaleoBios, 35, 39960. https://escholarship.org/uc/item/4ht19712

Long, R. A. \& Murry, P. A. 1995. Late Triassic (Carnian and Norian) tetrapods from the southwestern United States. New Mexico Museum of Natural History and Science Bulletin, 4, 1-254.

Lovelace, D. M. \& Lovelace, S. D. 2012. Paleoenvironments and paleoecology of a Lower Triassic invertebrate and vertebrate ichnoassemblage from the Red Peak Formation (Chugwater Group), central Wyoming. Palaios, 27, 636-656.

Lovelace, D., Huttenlocker, A. K., Pardo, J. D., Kufner, A. M., Chen, G.-H. \& Li, K. 2017. The first Late Triassic temnospondyl mass-mortality localities from the Popo Agie Formation, Fremont County, WY. Journal of Vertebrate Paleontology, Program and Abstracts, 2017, 153.

Lucas, S. G. 2001. Taphotaxon. Lethaia, 34, 30.

Lucas, S. G., Hunt, A. P. \& Bennett, S. C. 1985. Triassic vertebrates from east-central New Mexico in the Yale Peabody Museum. New Mexico Geological Society Guidebook, 36, 199-203.

Lucas, S. G., Rinehart, L. F., Heckert, A. B., Hunt, A. P. \& Spielmann, J. A. 2016. Rotten Hill: a Late Triassic bonebed in the Texas Panhandle, USA. New Mexico Museum of Natural History and Science Bulletin, 72, $1-97$.

Maddison, W. P. \& Maddison, D. R. 2017. Mesquite: a modular system for evolutionary analysis, version 3.31 . Available at http://mesquiteproject.org

Marsh, O. C. 1891. Geological horizons as determined by vertebrate fossils. American Journal of Science, 42, 336-338.

McHugh, J. B. 2012. Temnospondyl ontogeny and phylogeny, a window into terrestrial ecosystems during the PermianTriassic mass extinction. Unpublished $\mathrm{PhD}$ thesis, University of Iowa, $198 \mathrm{pp}$. 
Meyer, E. 1842. Labyrinthodonten - Genera. Neues Jahrbuch für Mineralogie, Geographie, Geologie, Paläontologie, 1842, 301-304.

Milner, A. 1989. Late extinctions of amphibians. Nature, 338, 117.

Milner, A. R. 1994. Late Triassic and Jurassic amphibians: fossil record and phylogeny. Pp. 5-22 in N. C. Fraser \& H.-D. Sues (eds) In the shadow of the dinosaurs: early Mesozoic tetrapods. Cambridge University Press, Cambridge.

Milner, A. R. \& Schoch, R. R. 2004. The latest metoposaurid amphibians from Europe. Neues Jahrbuch für Geologie und Paläontologie, Abhandlungen, 232, 231-252.

Moodie, R. L. 1908. The lateral line system in extinct Amphibia. Journal of Morphology, 19, 511-540.

Mueller, B. D. 2007. Koskinonodon Branson and Mehl, 1929, a replacement name for the preoccupied temnospondyl Buettneria Case, 1922. Journal of Vertebrate Paleontology, 27, 225.

Murry, P. A. 1989. Geology and paleontology of the Dockum Formation (Upper Triassic), West Texas and eastern New Mexico. Pp. 102-144 in S. G. Lucas \& A. P. Hunt (eds) Dawn of the age of dinosaurs in the American southwest. New Mexico Museum of Natural History and Science, Albuquerque.

Nesbitt, S. J. \& Stocker, M. R. 2008. The vertebrate assemblage of the Late Triassic Canjilon Quarry (northern New Mexico, USA), and the importance of apomorphybased assemblage comparisons. Journal of Vertebrate Paleontology, 28, 1063-1072.

Novas, F. E., Ezcurra, M. D., Chatterjee, S. \& Kutty, T. S. 2011. New dinosaur species from the Upper Triassic Upper Maleri and Lower Dharmaram formations of central India. Earth and Environmental Science Transactions of the Royal Society of Edinburgh, 101, 333-349.

Pardo, J. D., Small, B. J. \& Huttenlocker, A. K. 2017. Stem caecilian from the Triassic of Colorado sheds light on the origins of Lissamphibia. Proceedings of the National Academy of Sciences of the United States of America, 114, E5389-E5395.

Parker, W. G. 2013. Redescription and taxonomic status of specimens of Episcoposaurus and Typothorax, the earliest known aetosaurs (Archosauria: Suchia) from the Upper Triassic of western North America, and the problem of proxy 'holotypes'. Earth and Environmental Science Transactions of the Royal Society of Edinburgh, 103, $313-338$

Parker, W. G. 2018. Redescription of Calyptosuchus (Stagonolepis) wellesi (Archosauria: Pseudosuchia: Aetosauria) from the Late Triassic of the southwestern United States with a discussion of genera in vertebrate paleontology. PeerJ, 6, e4291. doi:10.7717/peerj.4291.

Romer, A. S. 1947. Review of the Labyrinthodontia. Bulletin of the Museum of Comparative Zoology, 99, 1-368.

Säve-Söderbergh, G. 1936. On the morphology of Triassic stegocephalians from Spitsbergen, and the interpretation of the endocranium in the Labyrinthodontia. Kungliga svenska Vetenskapsakademiens Handlingar, 16, 1-181.

Sawin, H. J. 1945. Amphibians from the Dockum Triassic of Howard County, Texas. University of Texas Publication, 4401, 361-399.

Schoch, R. R. 1999. Comparative osteology of Mastodonsaurus giganteus (Jaeger, 1828) from the Middle
Triassic (Lettenkeuper: Longobardian) of Germany (Baden-Württemberg, Bayern, Thüringen). Stuttgarter Beiträge zur Naturkunde (Serie B), 278, 1-175.

Schoch, R. R. 2000. The origin and intrarelationships of Triassic capitosaurid amphibians. Palaeontology, 43, 705-727.

Schoch, R. R. 2006. A complete trematosaurid amphibian from the Middle Triassic of Germany. Journal of Vertebrate Paleontology, 26, 29-43.

Schoch, R. R. 2008a. A new stereospondyl from the German Middle Triassic, and the origin of the Metoposauridae. Zoological Journal of the Linnean Society, 152, 79-113.

Schoch, R. R. 2008b. The Capitosauria (Amphibia): characters, phylogeny, and stratigraphy. Palaeodiversity, 1, 189-226.

Schoch, R. R. 2013. The evolution of major temnospondyl clades: an inclusive phylogenetic analysis. Journal of Systematic Palaeontology, 11(6), 673-705.

Schoch, R. R. \& Witzmann, F. 2009. Osteology and relationships of the temnospondyl genus Sclerocephalus. Zoological Journal of the Linnean Society, 157, 135-168.

Sengupta, D. P. 2002. Indian metoposaurid amphibians revised. Paleontological Research, 6, 41-65.

Shishkin, M. A. 1967. A brachyopid labyrinthodont from the Triassic of the Russia Platform. International Geologic Review, 9, 310-323.

Simpson, G. G. 1943. Criteria for genera, species, and subspecies in zoology and paleozoology. Annals of the New York Academy of Sciences, 44, 145-178.

Spielmann, J. A. \& Lucas, S. G. 2012. Tetrapod fauna of the Upper Triassic Redonda Formation east-central New Mexico: the characteristic assemblage of the Apachean land-vertebrate faunachron. New Mexico Museum of Natural History and Science Bulletin, 55, 1-119.

Steyer, J.-S. 2002. The first articulated trematosaur 'amphibian' from the Lower Triassic of Madagascar: implications for the phylogeny of the group. Palaeontology, 45, 771-793.

Sues, H.-D. \& Olsen, P. E. 2015. Stratigraphic and temporal context and faunal diversity of Permian-Jurassic continental tetrapod assemblages from the Fundy rift basin, eastern Canada. Atlantic Geology, 51, 139-205.

Sulej, T. 2002. Species discrimination of the Late Triassic temnospondyl amphibian Metoposaurus diagnosticus. Acta Palaeontologica Polonica, 47, 535-546.

Sulej, T. 2007. Osteology, variability, and evolution of Metoposaurus, a temnospondyl from the Late Triassic of Poland. Palaeontologica Polonica, 64, 29-139.

Swofford, D. L. 2002. PAUP*. Phylogenetic analysis using parsimony* 4.0. Sinauer, Sunderland, Massachusetts.

Szulc, J., Racki, G., Jewuła, K. \& Środoń, J. 2015. How many Upper Triassic bone-bearing levels are there in Upper Silesia (southern Poland)? A critical overview of stratigraphy and facies. Annales Societatis Geologorum Poloniae, 85, 587-626.

Teschner, E. M., Sander, P. M. \& Konietzko-Meier, D. 2017. Variability of growth pattern observed in Metoposaurus krasiejowensis humeri and its biological meaning. Journal of Iberian Geology, 44, 99-113.

Tsai, C. H. \& Fordyce, R. E. 2014. Juvenile morphology in baleen whale phylogeny. Naturwissenschaften, 101, 759-765. 
Tykoski, R. S. 2005. Anatomy, ontogeny, and phylogeny of coelophysoid theropods. Unpublished $\mathrm{PhD}$ thesis, University of Texas Austin, 572 pp.

Warren, A. \& Marsicano, C. 2000. A phylogeny of the Brachyopoidea (Temnospondyli, Stereospondyli). Journal of Vertebrate Paleontology, 20, 462-483.

Watson, D. M. S. 1919. The structure, evolution and origin of the Amphibia - the orders Rhachitomi and Stereospondyli. Philosophical Transactions of the Royal Society of London, Series B, 209, 1-73.

Wiens, J. J., Bonett, R. M. \& Chippindale, P. T. 2005. Ontogeny discombobulates phylogeny: paedomorphosis and higher-level salamander relationships. Systematic Biology, 54, 91-110.

Wilkinson, M. 1995. Coping with abundant missing entries in phylogenetic inference using parsimony. Systematic Biology, 4, 501-514.
Woodruff, D. C., Carr, T. C., Storrs, G. W., Waskow, K., Scannella, J. B., Nordén, K. K. \& Wilson, J. P. 2018. The smallest diplodocid skull reveals cranial ontogeny and growth-related dietary changes in the largest dinosaurs. Scientific Reports, 8, 14341. doi:10.1038/s41598-01832620-x.

Yates, A. M. \& Warren, A. A. 2000. The phylogeny of the 'higher' temnospondyls (Vertebrata: Choanata) and its implications for the monophyly and origins of the Stereospondyli. Zoological Journal of the Linnean Society, 128(1), 77-121.

Zittel, K. A. 1888. Handbuch der Paläeontologie. Abteilung 1. Paläozoologie. Band III. Vertebrata (Pisces, Amphibia, Reptilia, Aves). Oldenbourg, Münich and Leipzig, 900 pp.

Associate Editor: Susannah Maidment 